\title{
Experimental Results of Accelerated Long-term Durability Performance of E-glass Fiber Reinforced Polymer Composite Materials
}

\author{
By Jonathan Trovillion * \\ Hector Estrada \\ Hugh McManus \\ Ashok Kumar" \\ Larry D. Stephenson \\ William Lewis ${ }^{\star}$
}

Fiber reinforced polymer (FRP) composite materials have already been used in many infrastructure applications, including seismic rehabilitation, retrofitting, and repair of structural systems (for example, strengthening of concrete beams, slabs, and columns). FRP composites are ideal for these applications compared to traditional materials because of their inherent customizability, multi-functionality (including characteristics related to survivability), durability, and high specific properties (high strength-toweight and stiffness-to-weight ratios). However, these applications require materials to perform adequately over long periods of time in harsh environments, such as exposure to moisture and high temperatures. Therefore, it is important for engineers responsible for the design and maintenance of these systems to understand the longterm durability of the materials to these environmental stimuli.This paper presents results of experimental tests that can be used to estimate the service life of an FRP composite system. The results can be used to augment the current body of knowledge of observed material behavior and degradation mechanisms to create a practical method for estimating the service life of FRP composites. The results include the effects of transport phenomena (heat and moisture), degradation mechanisms (hygrothermal and material post-cure) using hygro-thermal degradation of E-glass/epoxy composites in accelerated tests under controlled temperatures and relative humidities. These results can also be used to calibrate predictive semi-empirical modes for degradation mechanisms for predicting the long-term service life of FRP composite materials used in civil infrastructure.

Keywords: Degradation mechanisms, Experimental tests, Fiber reinforced polymer, FRP composite properties, Post curing.

\footnotetext{
*U.S. Army Engineer Research and Development Center, USA. 'Professor, University of the Pacific, USA.

"U.S. Army Engineer Research and Development Center, USA.

'U.S. Army Engineer Research and Development Center, USA.

${ }^{\circ}$ U.S. Army Engineer Research and Development Center, USA.

`U.S. Army Engineer Research and Development Center, USA.
} 


\section{Introduction}

Despite extensive use of advanced glass and carbon fiber reinforced polymer composites in many applications (infrastructure, sporting, and aerospace industries), reported performance of these materials on some applications important to construction are mixed. Particularly, long-term performance has been questionable in some situations; FRP materials are susceptible to strength degradation over time when exposed to environmental factors such as moisture egress in combination with prolonged exposure to elevated temperatures and/or ultraviolet (UV) radiation. In these cases, the strength loss occurs from changes at the molecular level, which is known as material aging. The focus of the work presented here is on experimental data that can be used to calibrate models for degradation mechanisms for predicting the long-term service life of FRP composite materials used in civil infrastructure.

In general, any material used in critical applications (such as strengthening of concrete beams, slabs, and columns) is expected to perform satisfactorily for long periods of time under harsh environments, which may include exposure to moisture and high temperature. Therefore, to effectively predict the service life of FRP composites a fundamental understanding of the long-term durability and performance of these materials is essential.

\section{Literature Review}

Advances in composite manufacturing technology over the past decades have allowed large scale substitution (in certain sectors) of FRP composites for metallic and concrete components. The advances have been primarily a result of improved material properties due to better control of defects during processing, which led to a reduction of void content. Historically the U.S. composites industry has experienced high growth, an average rate of 6\% per year from 1960 to 2008 (MacNeil, 2010). Unfortunately, the industry closely follows the business cycle, which experienced a severe recession starting in 2008, causing a drop of over 25\% in composites output. Fortunately, the recovery began in 2010 and experienced a healthy growth rate through 2017; much of it in new segments of the industry. For instance, two of these industries include glass-reinforced epoxy piping for crude oil production and composite turbine components for wind energy production, where the growth is expected to be $20 \%$ per year. The current global growth forecast through 2022 is approximately 5\% per year (Mazumdar, 2018). In the U.S. the compound annual growth rate is expected to be $6.6 \%$; primarily driven by the transportation, construction, and aerospace sectors (Mazumdar, 2018), in that order.

Prior to the 2008 global economic recession, the civil construction industry was the largest user of composite materials with a volume share of nearly $30 \%$ (Mahieux, 2006). This was primarily driven by various niche applications, such as concrete reinforcing rods and tendons, wraps for seismic retrofit of columns, externally bonded reinforcement for strengthening of walls/beams/slabs, and 
composite bridge decks (Mahieux, 2006). Their use in these applications is predicated on performance attributes linked to their high specific properties (high stiffness-to-weight and strength-to-weight ratios), ease of installation in the field, potential lower system level cost, and the potential of long-term durability resulting in lower maintenance costs. Since FRP composites are still relatively unknown to practicing engineers and infrastructure systems planners, there are heightened concerns related to the overall durability of these materials; especially as related to sustained performance under harsh environmental conditions. This last issue is compounded by the lack of a comprehensive database of material durability properties and the lack of a thorough understanding of the long-term behavior of composites; particularly how durability is affected by various degradation agents. These are among the main challenges impeding widespread acceptance and implementation of these materials in civil infrastructure. With this fundamental problem resolved, practicing infrastructure engineers and designers will have the tools necessary to specify FRP composites in their designs, affording designers the opportunity to substitute composites for traditional civil infrastructure materials.

The three general categories of degradation agents that are relevant to FRP composites include: environmental (mainly temperature and moisture, also known as hygro-thermal), chemical (ionic attack, mainly oxygen and UV radiation), and mechanical (static and dynamic stress) (Foch, 1997). In this study we focus on combinations of sustained and transient thermal, hygral, and stress exposures.

Taktak et al., (2015) studied the effects of hygrothermal aging on mechanical properties of composites (yield stress, tensile strength and modulus, and total elongation. Experimental results were compared to micromechanics damage model. Arhant et al. (2016), presented results of mechanical properties test (tension and compression) for specimens aged under different humidity conditions. The purpose of the test was to use the results in a model for the effects of water diffusion in the mechanical properties of thick carbon fiber reinforced polyamide-6 composite cylinders immersed in sear water. They observed significant degradation in matrix-dominated properties.

The experimental data presented here can be used to calibrate durability models that are based on semi-empirical approaches. The data also contributes to a body of knowledge to synthesize and build on existing material behavior and degradation theories to capture major observed transport phenomena, degradation mechanisms, and mechanical behavior.

\section{Experimental Program}

Specimen fabrication and preparation procedures, as well as the test methods used to obtain the material properties are based on standard specifications. The accelerated material degradation test program includes details of the exposure environments. 
Test Plan

The test plan included the following three different series of sets:

1) Preliminary series used to focus the overall test plan, and to refine fabrication and testing procedures.

2) High temperature series of sets to isolate the effect of thermal degradation conducted on dry specimens at elevated temperatures.

3) Model prediction series of sets that can be used to validate degradation model predictions.

Depending on the series, data includes sets of specimens of various geometries subjected to combinations of different temperatures, stress levels (preloaded and initially unloaded), and relative humidity conditions. The properties obtained included inter-laminar shear strength (ILSS) using shortbeam shear (SBS) tests according to ASTM D2344 standard and longitudinal and transverse properties (tensile strength and stiffness) according to ASTM D3039 standard. The SBS test is a three-point flexural test of a short, thick specimen that induces an inter-laminar shear failure.

The preliminary series include sets of specimens cut from panels fabricated using $\left[0^{\circ}\right]_{42}$ unidirectional lay-ups prepared according to standard specifications (see Zoghi, 2014, pg. 65). Sets of specimens were tested to obtain ILSS and tensile properties at four different times; the first set was tested at time $t_{0}$ and was dubbed the baseline set. Specimens requiring conditioning were tested at three exposure times, $t_{1}, t_{2}$, and $t_{3}$, which corresponded to approximately two, four, and six weeks, respectively; as shown in Table 1 . The specimens subjected to accelerated degradation at controlled temperatures (at two different temperatures, $40^{\circ} \mathrm{C}$ or $\left.85^{\circ} \mathrm{C}\right)$ and relative humidity $(2 \%, 50 \%$, or $93 \%)$ conditions were placed in a Cincinnati Sub-Zero chamber, Model ZPH-32-1.5-H/AC (Cincinnati Sub-Zero Products Inc.). To capture the degradation effects of loading, specimens were either initially unloaded $(\mathrm{U})$ or preloaded $(\mathrm{P})$ to $2 \%$ of the ultimate tensile stress during hygro-thermal conditioning. Preloaded specimens were mounted on racks with springs and turnbuckles to apply the load. During environmental exposure, specimens were removed periodically at designated time intervals and subjected to mechanical (SBS or tensile) tests as listed in the test matrix shown in Table 1.

The second series of specimen sets were exposed to temperatures of $100^{\circ} \mathrm{C}$, $125^{\circ} \mathrm{C}$ and $150^{\circ} \mathrm{C}$ to isolate the thermal degradation mechanism as shown in Table 2. These specimens were also conditioned in the Cincinnati Sub-Zero chamber. To produce the dry condition, the humidity control was turned off. With temperatures at and above $100{ }^{\circ} \mathrm{C}$, it is assumed that moisture is driven out of the chamber representing a dry exposure condition. During the high temperature conditioning phase, specimens were also removed periodically at designated time intervals and subjected to SBS mechanical tests as indicated in the test matrix shown in Table 2. Preliminary results of these tests showed that the time for the material properties to stabilize under a given exposure condition significantly depends on temperature. In general, as the temperature increased, the tested property stabilized more 
quickly. This led to the decision to conduct the tests for the $150^{\circ} \mathrm{C}$ temperature specimens at shorter intervals than the $125^{\circ} \mathrm{C}$ temperature tests.

Table 1. Preliminary Test Matrix

\begin{tabular}{|c|c|c|c|c|c|c|c|c|}
\hline \multirow{2}{*}{$\begin{array}{c}\text { Time } \\
\text { (days) }\end{array}$} & \multirow{2}{*}{ Layup } & \multirow{3}{*}{ Specimen } & \multicolumn{6}{|c|}{$\begin{array}{l}\text { \# of specimens tested preloaded/\# of } \\
\text { specimens tested unloaded }(\mathrm{P} / \mathrm{U})\end{array}$} \\
\hline & & & \multicolumn{3}{|c|}{$40^{\circ} \mathrm{C}$ Temp. } & \multicolumn{3}{|c|}{$85^{\circ} \mathrm{C}$ Temp. } \\
\hline \multicolumn{2}{|c|}{ Relative Humidity (RH) $\rightarrow$} & & $2 \%$ & $50 \%$ & $93 \%$ & $2 \%$ & $50 \%$ & $93 \%$ \\
\hline \multirow[b]{2}{*}{$t_{0}=0$} & {$\left[0^{\circ}\right]_{42}$} & SBS & \multicolumn{6}{|c|}{ 0/5(baseline) } \\
\hline & {$\left[90^{\circ}\right]_{42}$} & $\begin{array}{c}90^{\circ} \\
\text { Tensile }\end{array}$ & \multicolumn{6}{|c|}{$0 / 2$ (baseline) } \\
\hline \multirow[b]{2}{*}{$t_{1}=14$} & {$\left[0^{\circ}\right]_{42}$} & SBS & $5 / 5$ & $5 / 5$ & $5 / 5$ & $5 / 5$ & $5 / 5$ & $7 / 5$ \\
\hline & {$\left[90^{\circ}\right]_{42}$} & $\begin{array}{c}90^{\circ} \\
\text { Tensile } \\
\end{array}$ & $2 / 2$ & $1 / 2$ & $2 / 2$ & $2 / 2$ & $2 / 2$ & $2 / 2$ \\
\hline \multirow[b]{2}{*}{$t_{2}=28$} & {$\left[0^{\circ}\right]_{42}$} & SBS & $5 / 5$ & $5 / 5$ & $5 / 5$ & $5 / 5$ & $5 / 0$ & $5 / 5$ \\
\hline & {$\left[90^{\circ}\right]_{42}$} & $\begin{array}{c}90^{\circ} \\
\text { Tensile }\end{array}$ & $2 / 2$ & $2 / 2$ & $2 / 2$ & $2 / 2$ & $2 / 0$ & $2 / 2$ \\
\hline \multirow[b]{2}{*}{$t_{3}=42$} & {$\left[0^{\circ}\right]_{42}$} & SBS & $5 / 5$ & $4 / 5$ & $5 / 5$ & $5 / 5$ & $0 / 5$ & $0 / 0$ \\
\hline & {$\left[90^{\circ}\right]_{42}$} & $\begin{array}{c}90^{\circ} \\
\text { Tensile }\end{array}$ & $2 / 2$ & $2 / 2$ & $2 / 2$ & $2 / 2$ & $2 / 2$ & $0 / 0$ \\
\hline
\end{tabular}

Table 2. High Temperature Test Matrix

\begin{tabular}{|c|c|c|c|c|c|}
\hline \multirow[t]{2}{*}{$\begin{array}{c}\text { Time } \\
\text { (days) }\end{array}$} & \multirow[t]{2}{*}{ Layup } & \multirow[t]{2}{*}{ Specimen } & \multicolumn{3}{|c|}{$\begin{array}{c}\text { \# of specimens tested preloaded/\# } \\
\text { of specimens tested unloaded } \\
(\mathrm{P} / \mathrm{U})\end{array}$} \\
\hline & & & $100^{\circ} \mathrm{C}$ & $125^{\circ} \mathrm{C}$ & $150^{\circ} \mathrm{C}$ \\
\hline \multirow{3}{*}{$t_{0}=0$} & {$\left[0^{\circ}\right]_{42}$} & SBS & \multicolumn{3}{|c|}{ 0/5 (baseline) } \\
\hline & {$\left[90^{\circ}\right]_{42}$} & $90^{\circ}$ Tensile & \multicolumn{3}{|c|}{$0 / 2$ (baseline) } \\
\hline & {$\left[0^{\circ}\right]_{10}$} & Tensile & \multicolumn{3}{|c|}{ 0/5 (baseline) } \\
\hline \multirow{2}{*}{$t_{1}=3$} & {$\left[0^{\circ}\right]_{42}$} & SBS & - & - & $5 / 5$ \\
\hline & {$\left[0^{\circ}\right]_{10}$} & Tensile & - & - & $3 / 3$ \\
\hline \multirow{2}{*}{$t_{2}=4$} & {$\left[0^{\circ}\right]_{42}$} & SBS & $5 / 5$ & $5 / 5$ & - \\
\hline & {$\left[0^{\circ}\right]_{10}$} & Tensile & $3 / 3$ & $3 / 3$ & - \\
\hline \multirow{2}{*}{$t_{3}=7$} & {$\left[0^{\circ}\right]_{42}$} & SBS & $5 / 5$ & - & $5 / 5$ \\
\hline & {$\left[0^{\circ}\right]_{10}$} & Tensile & $3 / 3$ & - & $3 / 3$ \\
\hline \multirow{2}{*}{$t_{4}=8$} & {$\left[0^{\circ}\right]_{42}$} & SBS & - & $5 / 5$ & - \\
\hline & {$\left[0^{\circ}\right]_{10}$} & Tensile & - & $3 / 3$ & - \\
\hline \multirow{2}{*}{$t_{5}=11$} & {$\left[0^{\circ}\right]_{42}$} & SBS & $5 / 5$ & - & $5 / 5$ \\
\hline & {$\left[0^{\circ}\right]_{10}$} & Tensile & $3 / 3$ & - & $3 / 3$ \\
\hline \multirow{2}{*}{$t_{6}=13$} & {$\left[0^{\circ}\right]_{42}$} & SBS & - & $5 / 5$ & - \\
\hline & {$\left[0^{\circ}\right]_{10}$} & Tensile & - & $2 / 2$ & - \\
\hline
\end{tabular}

The last series included specimen sets that were tested to provide data that can be used to predict long-term material behavior or validate degradation model 
predictions. The panels for these tests included lay-ups of $\left[0^{\circ}\right]_{10}$ and $\left[0^{\circ}\right]_{42}$ unidirectional, and $\left[0^{\circ} / 90^{\circ} / \pm 45^{\circ}\right]_{\mathrm{s}}$ quasi-isotropic. The $\left[0^{\circ}\right]_{42}$ specimens were used to obtain inter-laminar shear strength; while the $\left[0^{\circ}\right]_{10}$ unidirectional and $\left[0^{\circ} / 90^{\circ} / \pm 45^{\circ}\right]_{\mathrm{s}}$ quasi-isotropic specimens were used to obtain tensile strength and stiffness properties. All these specimens were exposed to two different exposure conditions: $50 \%$ relative humidity at $85^{\circ} \mathrm{C}$ and dry at $125^{\circ} \mathrm{C}$. Sets of specimens were tested at different times and conditioned as indicated in the test matrix shown in Table 3 .

Table 3. Model Prediction Test Matrix

\begin{tabular}{|c|c|c|c|c|}
\hline \multirow{2}{*}{$\begin{array}{c}\text { Time } \\
\text { (days) }\end{array}$} & \multirow{2}{*}{ Layup } & \multirow[t]{2}{*}{ Specimen } & \multicolumn{2}{|c|}{$\begin{array}{l}\text { \# of specimens tested preloaded/\# of } \\
\text { specimens tested unloaded }(\mathrm{P} / \mathrm{U})\end{array}$} \\
\hline & & & $85^{\circ} \mathrm{C}$ at $50 \% \mathrm{RH}$ & $125^{\circ} \mathrm{C}$ and dry \\
\hline \multirow{3}{*}{$t_{0}=0$} & {$\left[0^{\circ}\right]_{42}$} & SBS & \multicolumn{2}{|c|}{ 0/6 (baseline) } \\
\hline & {$\left[0^{\circ}\right]_{10}$} & Tensile & \multicolumn{2}{|c|}{ 0/5 (baseline) } \\
\hline & Quasi & Tensile & \multicolumn{2}{|c|}{ 0/5 (baseline) } \\
\hline \multirow{3}{*}{$t_{1}=7$} & {$\left[0^{\circ}\right]_{42}$} & SBS & - & $6 / 6$ \\
\hline & {$\left[0^{\circ}\right]_{10}$} & Tensile & - & 5 \\
\hline & Quasi & Tensile & - & 5 \\
\hline \multirow{3}{*}{$t_{2}=14$} & {$\left[\begin{array}{c}\left.0^{\circ}\right]_{42} \\
\end{array}\right.$} & 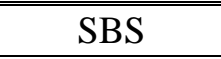 & $6 / 6$ & $\overline{5 / 6}$ \\
\hline & {$\left[0^{\circ}\right]_{10}$} & Tensile & 8 & 5 \\
\hline & Quasi & Tensile & 5 & 5 \\
\hline \multirow{3}{*}{$t_{3}=21$} & {$\left[0^{\circ}\right]_{42}$} & SBS & 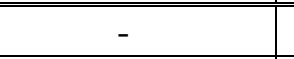 & $6 / 6$ \\
\hline & {$\left[0^{\circ}\right]_{10}$} & Tensile & - & 5 \\
\hline & Quasi & Tensile & - & 5 \\
\hline \multirow{3}{*}{$t_{4}=28$} & {$\left[0^{\circ}\right]_{42}$} & SBS & $6 / 6$ & 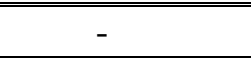 \\
\hline & {$\left[0^{\circ}\right]_{10}$} & Tensile & 8 & - \\
\hline & Quasi & Tensile & 5 & - \\
\hline \multirow{3}{*}{$t_{5}=42$} & {$\left[0^{\circ}\right]_{42}$} & SBS Loaded & $6 / 6$ & 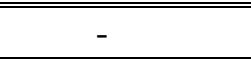 \\
\hline & {$\left[0^{\circ}\right] 10$} & Tensile & 8 & - \\
\hline & Quasi & Tensile & 5 & - \\
\hline
\end{tabular}

\section{Test Specimens}

\section{$\underline{\text { Materials }}$}

E-glass/epoxy was chosen for the study because this material combination is one of the most popular composites for infrastructure applications. The specific materials consisted of Hexcel unidirectional E-glass (6 oz per square yard) cloth (95\% in fiber direction, 5\% perpendicular to fiber direction) from Fiberglassite.com and SC-780 toughened epoxy resin from Applied Poleramic, Inc. 


\section{$\underline{\text { Panel Fabrication }}$}

The panels were fabricated using the resin infusion molding (RIM) technique. This is a manufacturing process that has been proven cost effective for applications requiring a high degree of quality control. Several E-glass/epoxy composite panels of various sizes and layups were manufactured (see list below). To form the panels, E-glass material was cut and stocked in predetermined layups $\left(\left[0^{\circ}\right]_{10},\left[0^{\circ}\right]_{42}\right.$, and $\left.\left[0^{\circ} / 90^{\circ} / \pm 45^{\circ}\right]_{\mathrm{s}}\right)$ and placed in a vacuum bagging system; the resin was then infused at full vacuum and held for 24 hours, after which the panels were removed from the vacuum bag. No post cure was used; rather the panels remained in an indoor environment at room temperature until they were cut into test specimens. Panel layups and sizes are:

1. $\left[0^{\circ}\right]_{10}$ unidirectional, $30 \mathrm{~cm}$ by $95 \mathrm{~cm}(12 "$ by $37.5 ")$ and $0.15 \mathrm{~cm}(0.06 ")$ thick.

2. $\left[0^{\circ}\right]_{42}$ unidirectional, $30 \mathrm{~cm}$ by $95 \mathrm{~cm}(12 "$ by $37.5 ")$ and $0.64 \mathrm{~cm}(0.25 ")$ thick; this was also cut in the transverse direction to produce $\left[90^{\circ}\right]_{42}$ unidirectional specimens.

3. $\left[0^{\circ} / 90^{\circ} / \pm 45^{\circ}\right]_{\mathrm{s}}$ quasi-isotropic, $46 \mathrm{~cm}$ by $46 \mathrm{~cm}\left(18 "\right.$ by $\left.18^{\prime \prime}\right)$ and 0.15 $\mathrm{cm}\left(0.058^{\prime \prime}\right)$ thick.

\section{Fiber Volume Fraction and Composite Density}

The relative proportions of fiber and matrix are generally the most important factors governing the properties of a composite. These relative proportions are based on volume fractions of the constituent materials, which can be calculated from weight fractions obtained through the burn-off method (ASTM D2584). Five $2.5 \mathrm{~cm}$ by $2.5 \mathrm{~cm}$ by $0.64 \mathrm{~cm}$ ( 1 " by 1 " by 0.25 ") samples from the $\left[0^{\circ}\right]_{42}$ panels were used to determine the volume fractions and the composite density, see Table 4 . The proportions for the $\left[0^{\circ}\right]_{10}$ panels were assumed to be the same as those of the $\left[0^{\circ}\right]_{42}$ panels. For the quasi-isotropic case, the density and fiber volume fraction were extrapolated from the proportions of the $\left[0^{\circ}\right]_{42}$ case. The process entailed using the measured thicknesses of the $\left[0^{\circ} / 90^{\circ} / \pm 45^{\circ}\right]_{\mathrm{S}}$ to determine the increase in thickness due to the additional epoxy rich areas. On average, the quasi-isotropic panels were 0.021-inch thicker than a comparable eight-ply unidirectional sample. This resulted in a decrease in the density and fiber volume fraction, which were estimated to be $1.30 \mathrm{~g} / \mathrm{cm}^{3}$ and $38 \%$, respectively.

Table 4.Volume Fractions and Densities of E-glass/Epoxy $\left[0^{\circ}\right]_{42}$ Panels

\begin{tabular}{|c|c|c|c|c|}
\hline \multirow{2}{*}{ Constituent } & \multicolumn{2}{|c|}{ Density $\left(\mathbf{g} / \mathbf{c m}^{\mathbf{3}}\right)$} & \multicolumn{2}{c|}{ Volume fraction (\%) } \\
& average & Stddev & average & Stddev \\
\hline \hline Composite & 1.81 & 0.027 & - & - \\
\hline Fiber & $2.54 *$ & - & 53.8 & 1.00 \\
\hline Matrix & 1.16 & 0.008 & 38.2 & 0.83 \\
\hline Voids & - & - & 7.98 & 1.29 \\
\hline
\end{tabular}

*Value for a similar material (Zoghi, 2014). 


\section{Specimen Preparation}

All panels were cut into $0.28 \mathrm{~m}$ by $0.025 \mathrm{~m}$ (11" by 1") coupons using the water jet cutting technique. The unidirectional panels were first divided into three sections: left, center, and right. Specimens cut from these three sections were divided into two groups: those cut in the axial fiber direction $\left[0^{\circ}\right]$ (right section) and those cut in the transverse fiber direction (left and center sections), which resulted in $\left[90^{\circ}\right]$ specimens. The $\left[0^{\circ}\right]$ specimens were used to determine the longitudinal properties (strength and stiffness). The $\left[90^{\circ}\right]$ specimens were used for two purposes: to determine the transverse strength of the material and to cut the SBS test specimens. After cutting, the specimens were wiped clean and placed in a desiccator to remove any residual moisture. To ensure that the samples were dry, they were weighed periodically until their change in weight was acceptably small. The specimens were then mounted on the racks and placed in the temperature/humidity chamber.

After conditioning, the $\left[90^{\circ}\right]_{42}$ coupons were further cut into nominally 1 " $\mathrm{x} 0.5$ " $\mathrm{x} 0.25$ " SBS specimens from the central region of the coupons. The cuts were made using a slow speed diamond saw. The rationale for cutting the SBS specimens from larger conditioned coupons was to minimize undesirable moisture absorption along the cut edges; only the $1.3 \mathrm{~cm}\left(0.5^{\prime \prime}\right)$ edges were exposed. The $\left[0^{\circ}\right]_{10}$ and $\left[ \pm 45^{\circ} / 0^{\circ} / 90^{\circ}\right]_{\mathrm{s}}$ layup coupons required no further preparation before testing.

\section{Results and Discussion}

In this section, we present the experimental results of the tests to obtain preliminary data, high temperature data, and model prediction data. This data was analyzed according to their corresponding ASTM standards. The data from the SBS tests include inter-laminar shear strength. The data from the tensile tests include tensile strength, modulus of elasticity, and Poisson's ratio. All tests were conducted at room temperature following the corresponding test matrices given in Tables 1-3.

\section{Preliminary Data}

The first series was conducted to focus the experimental program efforts and is based on test matrix listed in Table 1. The data indicates that the time for convergence of tested properties primarily depended on the environmental conditioning temperature - as the temperature increased, the time to convergence of the tested properties decreased. Results of these tests were used to establish the test plan for the different environmental conditions. 


\section{$\underline{\text { Baseline Data }}$}

Tough strict quality control measures were followed in the entire fabrication process, variations in material properties are inevitable. To compare the variation in properties in all composite panels, the un-conditioned properties of each panel were measured. These properties also served as a baseline to capture any changes over time. The baseline results are listed in each table for time equals zero days. The data is presented in kilo-pounds per square inch (ksi), (in all cases, the data can easily be converted to metric units). For cases where multiple panels were used in a single data set, the baseline values were obtained by averaging values of corresponding panels.

\section{Intern-laminar Shear Strength, SBS Test Data}

Composite inter-laminar shear failure results in a series of horizontal cracks that form at the ends and move inward toward the loading noses of the threepoint bending test fixture. The inter-laminar shear strength degradation data for the SBS tests from the six exposure conditions are presented in this subsection.

Table 5 lists the experimental results for the environmentally conditioned specimens preloaded to $2 \%$ of the ultimate transverse tensile strength. This was determined to be 40 pounds using the average value of the ultimate transverse tensile strength baseline results of $7806 \mathrm{psi}$; that is, $7806 \mathrm{psi}(1 \mathrm{in})(0.25 \mathrm{in})$ $(0.02)=39 \mathrm{lbs}$. The data for $40^{\circ} \mathrm{C}$ at relative humidities of $2 \%, 50 \%$, and $93 \%$ is plotted in Figure 1. In this case, all three humidity conditions show a slight increase in inter-laminar shear strength (ILSS) at 14 days. This is followed by degradation for all cases at 28 days. The degradation continues for the wet $(93 \%$ $\mathrm{RH})$ condition; however, the dry $(2 \% \mathrm{RH})$ and medium $(50 \% \mathrm{RH})$ humidity conditions show no discernible degradation past 28 days.

The data for the $85^{\circ} \mathrm{C}$ and stressed cases at relative humidities of $2 \%, 50 \%$, and $93 \%$ is plotted in Figure 2. In this case, the dry $(2 \% \mathrm{RH})$ condition shows a continuous ILSS increase over the time intervals. The medium $(50 \% \mathrm{RH})$ humidity condition shows a slight increase after 14 days, followed by a small decrease at 28 days. The wet $(93 \% \mathrm{RH})$ condition shows a continuous degradation over all time intervals. Note that data is missing for the medium and wet conditions at 35 days.

Table 5. ILSS for Preloaded, Environmentally Conditioned Specimens

\begin{tabular}{|c|c|c|c|c|c|c|c|c|c|c|c|c|}
\hline \multirow{3}{*}{$\begin{array}{c}\text { Time } \\
\text { (days) }\end{array}$} & \multicolumn{6}{|c|}{$40^{\circ} \mathrm{C}$ Exposure } & \multicolumn{6}{|c|}{$85^{\circ} \mathrm{C}$ Exposure } \\
\hline & \multicolumn{2}{|c|}{$2 \% \mathrm{RH}$} & \multicolumn{2}{|c|}{$50 \%$ RH } & \multicolumn{2}{|c|}{$93 \% \mathrm{RH}$} & \multicolumn{2}{|c|}{$2 \% \mathrm{RH}$} & \multicolumn{2}{|c|}{$50 \% \mathrm{RH}$} & \multicolumn{2}{|c|}{$93 \% \mathrm{RH}$} \\
\hline & $\begin{array}{c}\text { ILSS } \\
(\mathrm{ksi})\end{array}$ & $\begin{array}{c}\mathrm{SD} \\
(\mathrm{ksi})\end{array}$ & $\begin{array}{c}\text { ILSS } \\
(\mathrm{ksi})\end{array}$ & $\begin{array}{c}\mathrm{SD} \\
(\mathrm{ksi})\end{array}$ & $\begin{array}{c}\text { ILSS } \\
(\mathrm{ksi})\end{array}$ & $\begin{array}{c}\mathrm{SD} \\
(\mathrm{ksi})\end{array}$ & $\begin{array}{c}\text { ILSS } \\
(\mathrm{ksi})\end{array}$ & $\begin{array}{c}\mathrm{SD} \\
(\mathrm{ksi})\end{array}$ & $\begin{array}{c}\text { ILSS } \\
(\mathrm{ksi})\end{array}$ & $\begin{array}{c}\text { SD } \\
(\mathrm{ksi})\end{array}$ & $\begin{array}{c}\text { ILSS } \\
(\mathrm{ksi})\end{array}$ & $\begin{array}{c}\mathrm{SD} \\
(\mathrm{ksi})\end{array}$ \\
\hline 0 & 6.88 & 0.14 & 6.09 & 0.15 & 7.01 & 0.18 & 6.09 & 0.15 & 6.62 & 0.17 & 6.87 & 0.32 \\
\hline 14 & 8.18 & 0.12 & 7.57 & 0.31 & 8.24 & 0.93 & 7.69 & 0.66 & 6.87 & 0.12 & 4.37 & 0.08 \\
\hline 28 & 6.44 & 0.82 & 6.81 & 0.32 & 6.07 & 0.15 & 8.23 & 0.14 & 6.84 & 0.10 & 4.25 & 0.07 \\
\hline 35 & - & - & - & - & - & - & 8.64 & 0.28 & - & - & - & - \\
\hline 42 & 7.28 & 0.13 & 7.43 & 0.17 & 5.12 & 0.45 & - & - & - & - & - & - \\
\hline
\end{tabular}


Figures 1 and 2 clearly show changes in the material properties as the specimens are environmentally conditioned. The data is meant to show accelerated degradation of the composite over time. It appears that the material only experienced degradation for the specimens conditioned at $85^{\circ} \mathrm{C} / 93 \% \mathrm{RH}$, which is associated with a hygro-thermal degradation mechanism. This is primarily driven by the presence of moisture and tends to decrease (or degrade) the properties with time. Second, the effect of temperature appears to initially increase ILSS, which is probably due to post curing of the epoxy matrix at temperatures above room temperature.

Figure 1. ILSS from SBS Test for $40^{\circ} \mathrm{C}$ and Preloaded with 40-lbs

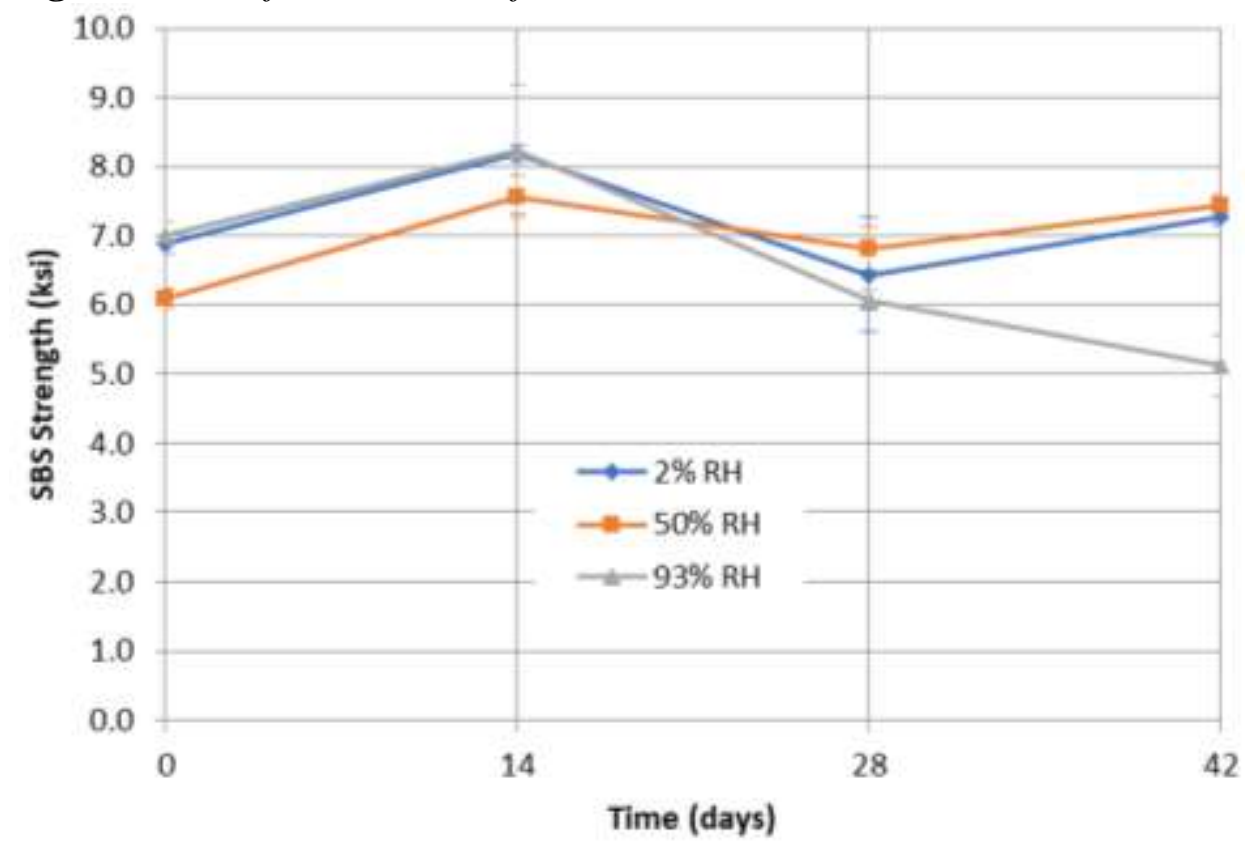

The results for the specimens initially unloaded presented in Table 6 also show changes in the material properties as the specimens are environmentally conditioned; with the most severe effect coming from the hygro-thermal degradation mechanism. Also, the effect of temperature appears to initially increase the properties, probably due to post curing of the epoxy matrix at the higher temperatures. 
Figure 2. ILSS from SBS Test for $85^{\circ} \mathrm{C}$ and Preloaded with 40-lbs

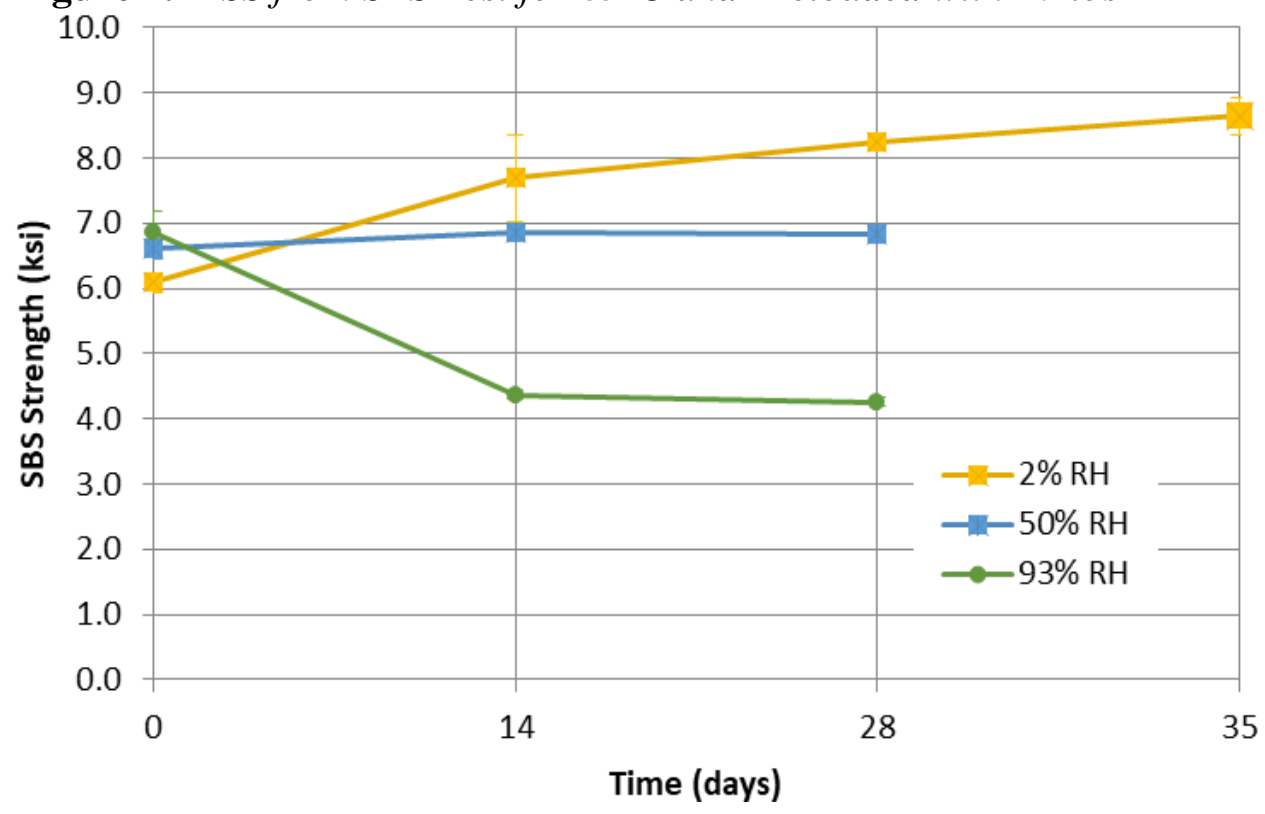

Table 6. ILSS for Initially Unloaded, Environmentally Conditioned Specimens

\begin{tabular}{|c|c|c|c|c|c|c|c|c|c|c|c|c|}
\hline \multirow{3}{*}{$\begin{array}{l}\text { Time } \\
\text { (days }\end{array}$} & \multicolumn{6}{|c|}{$40^{\circ} \mathrm{C}$ Exposure } & \multicolumn{6}{|c|}{$85^{\circ} \mathrm{C}$ Exposure } \\
\hline & \multicolumn{2}{|c|}{$2 \% \mathrm{RH}$} & \multicolumn{2}{|c|}{$50 \% \mathrm{RH}$} & \multicolumn{2}{|c|}{$93 \% \mathrm{RH}$} & \multicolumn{2}{|c|}{$2 \% \mathrm{RH}$} & \multicolumn{2}{|c|}{$50 \%$ RH } & \multicolumn{2}{|c|}{$93 \% \mathrm{RH}$} \\
\hline & $\begin{array}{l}\text { ILSS } \\
\text { (ksi) }\end{array}$ & $\begin{array}{c}\text { SD } \\
\text { (ksi) }\end{array}$ & $\begin{array}{c}\text { ILSS } \\
\text { (ksi) }\end{array}$ & $\begin{array}{c}\text { SD } \\
\text { (ksi) }\end{array}$ & $\begin{array}{c}\text { ILSS } \\
\text { (ksi) }\end{array}$ & $\begin{array}{c}\text { SD } \\
\text { (ksi) }\end{array}$ & $\begin{array}{c}\text { ILSS } \\
\text { (ksi) }\end{array}$ & $\begin{array}{c}\text { SD } \\
(\mathrm{ksi})\end{array}$ & $\begin{array}{c}\text { ILSS } \\
\text { (ksi) }\end{array}$ & $\begin{array}{c}\text { SD } \\
\text { (ksi) }\end{array}$ & $\begin{array}{l}\text { ILSS } \\
\text { (ksi) }\end{array}$ & $\begin{array}{c}\text { SD } \\
\text { (ksi) }\end{array}$ \\
\hline 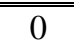 & 7. & 0 & 26.62 & $\overline{0.2}$ & 7.4 .4 & 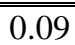 & 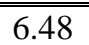 & 0.23 & $\begin{array}{c}6.80 \\
\end{array}$ & 0. & 6.60 & 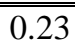 \\
\hline 14 & 7.67 & 0. & 7.74 & 0.25 & 4.96 & 0.2 & 8. & 0.1 & 6.88 & 0.30 & 4.84 & 0.06 \\
\hline 28 & 7.85 & 0.08 & 7.76 & 0.20 & 5.92 & 0.22 & 6.81 & 0.25 & 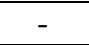 & - & 4.50 & 0.08 \\
\hline 35 & - & - & - & - & - & - & 7.69 & 0.16 & - & - & - & - \\
\hline 42 & 7.78 & 0.12 & 7.22 & 0.37 & 6.76 & 0.50 & & & 6.93 & 0.38 & - & \\
\hline
\end{tabular}

The effect of stress conditioning is shown in Figure 3. The data for the $93 \% \mathrm{RH}$ at $85^{\circ} \mathrm{C}$ preloaded and unloaded is compared. From the plots of the two load conditions; preloading has some degradation effect, with the strength of the preloaded specimens decreasing faster than the unloaded case - the decrease is even faster considering the fact that the baseline value for the preloaded specimens is higher than that for the unloaded specimens. This degradation may be the result of creating more voids as the specimens are stretched and additional moisture ingress into the material, causing further degradation of the matrix material.

\section{$\underline{\text { Tensile Tests Results }}$}

The tensile tests were simple axial pull to failure using wedge grips in a United Test machine. The material properties used to investigate degradation were the ultimate transverse tensile strength and transverse tensile modulus of elasticity. The longitudinal properties for the 42-ply specimens were not tested because they are fiber dominated. That is, fibers provide high stiffness and 
strength in the longitudinal (fiber) direction, but low properties in the transverse (matrix-dominated) direction.

Figure 3. Preloaded vs. Unloaded ILSS from SBS Test for $93 \%$ RH at $85^{\circ} \mathrm{C}$

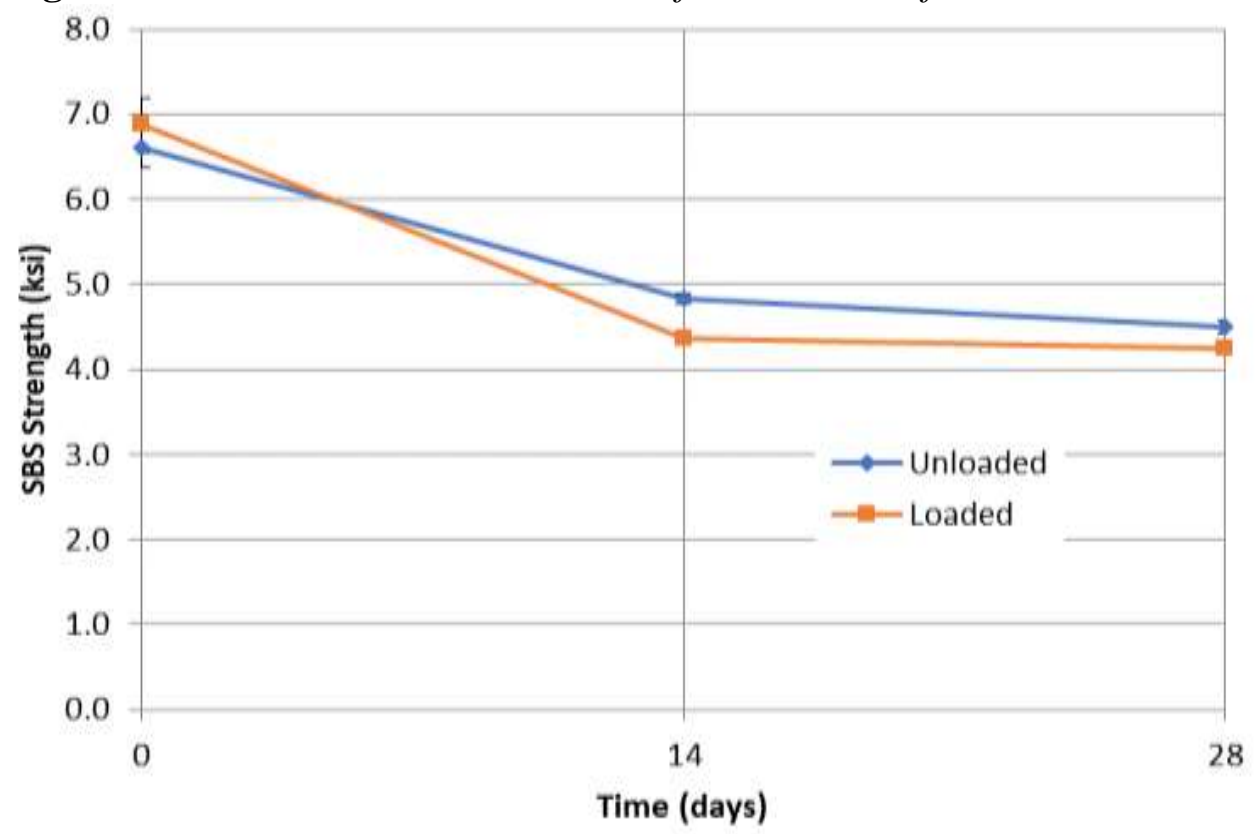

Transverse Tensile Strength

Table 7 gives the experimental results for the environmentally conditioned preloaded specimens; while Table 8 gives the experimental results for the initially unloaded specimens. In both cases, the results follow similar trends as the SBS test data. Though, there are some differences in transverse tensile strength as the specimens are environmentally conditioned; degradation is only observed for the wet $(93 \% \mathrm{RH})$ condition. The most severe effect comes from a hygro-thermal degradation mechanism. Again, the data was meant to show accelerated degradation of the composite over time. It appears that the material only experienced consistent degradation for the specimens conditioned at $85^{\circ} \mathrm{C} / 93 \%$ $\mathrm{RH}$. Some of the other specimens show an increase in properties. This is probably due to post cure in the composites at temperatures above room temperature.

Table 7.Transverse Tensile Strength (TTS) for Preloaded $\left[90^{\circ}\right]_{42}$ Specimens

\begin{tabular}{|c|c|c|c|c|c|c|c|c|c|c|c|c|}
\hline \multirow{3}{*}{$\begin{array}{l}\text { Time } \\
\text { (days) }\end{array}$} & \multicolumn{6}{|c|}{$40^{\circ} \mathrm{C}$ Exposure } & \multicolumn{6}{|c|}{$85^{\circ} \mathrm{C}$ Exposure } \\
\hline & \multicolumn{2}{|c|}{$2 \% \mathrm{RH}$} & \multicolumn{2}{|c|}{$50 \% \mathrm{RH}$} & \multicolumn{2}{|c|}{$93 \% \mathrm{RH}$} & \multicolumn{2}{|c|}{$2 \% \mathrm{RH}$} & \multicolumn{2}{|c|}{$50 \%$ RH } & \multicolumn{2}{|c|}{$93 \% \mathrm{RH}$} \\
\hline & $\begin{array}{l}\text { TTS } \\
\text { (ksi) }\end{array}$ & $\begin{array}{c}\text { SD } \\
(\mathrm{ksi})\end{array}$ & $\begin{array}{l}\text { TTS } \\
\text { (ksi) }\end{array}$ & $\begin{array}{r}\text { SD } \\
(\mathrm{ksi})\end{array}$ & & $\begin{array}{r}\text { SD } \\
(\mathrm{ksi})\end{array}$ & & SD & $\begin{array}{l}\text { TTS } \\
(\mathrm{ksi}) \\
\end{array}$ & SD & $\begin{array}{l}\text { TTS } \\
\text { (ksi) }\end{array}$ & $\begin{array}{l}\text { SD } \\
\text { (ksi) }\end{array}$ \\
\hline 0 & 8.73 & 0. & 7.27 & & & & & & 7.55 & 49 & & \\
\hline 14 & & & 7. & & & & & & 6.91 & 0.0 & 4. & 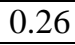 \\
\hline 28 & 1.90 & 1.0 & 7.91 & 0. & 5.29 & 0.01 & 32 & & 6.97 & 0.03 & 3.69 & 0.50 \\
\hline 35 & & & & & & & 1.96 & & & & & 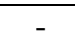 \\
\hline 42 & 00 & 0.0 & 7.94 & & 5.70 & . & & & 6.97 & 0.67 & & \\
\hline
\end{tabular}


The effect of stress conditioning is shown in Figure 4. The data for the 93\% RH at $85^{\circ} \mathrm{C}$ preloaded and unloaded are compared in the graph. For this case, there is no change at 14 days, but after that, loading has some degradation effect, with the strength of the loaded specimens decreasing faster than the unloaded case.

Table 8. Transverse Tensile Strength (TTS) for Unloaded $\left[90^{\circ}\right]_{42}$ Specimens

\begin{tabular}{|c|c|c|c|c|c|c|c|c|c|c|c|c|}
\hline \multirow{3}{*}{$\begin{array}{l}\text { Time } \\
\text { (days) }\end{array}$} & \multicolumn{6}{|c|}{$40^{\circ} \mathrm{C}$ Exposure } & \multicolumn{6}{|c|}{$85^{\circ} \mathrm{C}$ Exposure } \\
\hline & \multicolumn{2}{|c|}{$2 \% \mathrm{RH}$} & \multicolumn{2}{|c|}{$50 \% \mathrm{RH}$} & \multicolumn{2}{|c|}{$93 \% \mathrm{RH}$} & \multicolumn{2}{|c|}{$2 \% \mathrm{RH}$} & \multicolumn{2}{|c|}{$50 \%$ RH } & \multicolumn{2}{|c|}{$93 \%$ RH } \\
\hline & $\begin{array}{l}\text { TTS } \\
\text { (ksi) }\end{array}$ & $\begin{array}{l}\text { SD } \\
\text { (ksi) }\end{array}$ & $\begin{array}{l}\text { TTS } \\
\text { (ksi) }\end{array}$ & $\begin{array}{l}\text { SD } \\
\text { (ksi) }\end{array}$ & $\begin{array}{l}\text { TTS } \\
\text { (ksi) }\end{array}$ & $\begin{array}{c}\text { SD } \\
\text { (ksi) }\end{array}$ & $\begin{array}{l}\text { TTS } \\
\text { (ksi) }\end{array}$ & $\begin{array}{c}\text { SD } \\
\text { (ksi) }\end{array}$ & $\begin{array}{l}\text { TTS } \\
\text { (ksi) }\end{array}$ & $\begin{array}{c}\text { SD } \\
\text { (ksi) }\end{array}$ & $\begin{array}{l}\text { TTS } \\
\text { (ksi) }\end{array}$ & $\begin{array}{l}\text { SD } \\
\text { (ksi) }\end{array}$ \\
\hline$\overline{0}$ & $\overline{88 .}$ & $\bar{~} \overline{0 .}$ & \begin{tabular}{ll|}
7.34 \\
\end{tabular} & $\overline{\overline{0}}$ & ב & $\overline{\overline{11}}$ & $\overline{c 7.57}$ & & 7.55 & $\overline{c 0.49}$ & $\overline{c 7.57}$ & $\overline{77}$ \\
\hline 14 & 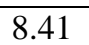 & 0.0 & 9.27 & 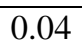 & 5.78 & 0 & 7.6 & 0.04 & 6.20 & 1.61 & 4.59 & 84 \\
\hline 28 & 8.51 & 0.46 & 7.64 & 0.45 & 5.79 & 0.12 & 7.39 & 0.31 & - & - & 4.36 & 0.26 \\
\hline 35 & - & - & - & - & - & . & 7.15 & 1.00 & - & - & - & - \\
\hline 42 & 8.17 & 0.28 & 8.06 & 0.48 & 6.87 & 0.29 & & - & 7.11 & 0.25 & & - \\
\hline
\end{tabular}

Figure 4. Preloaded vs. Unloaded TTS for $93 \%$ RH/ $85^{\circ} \mathrm{C}$ Specimens

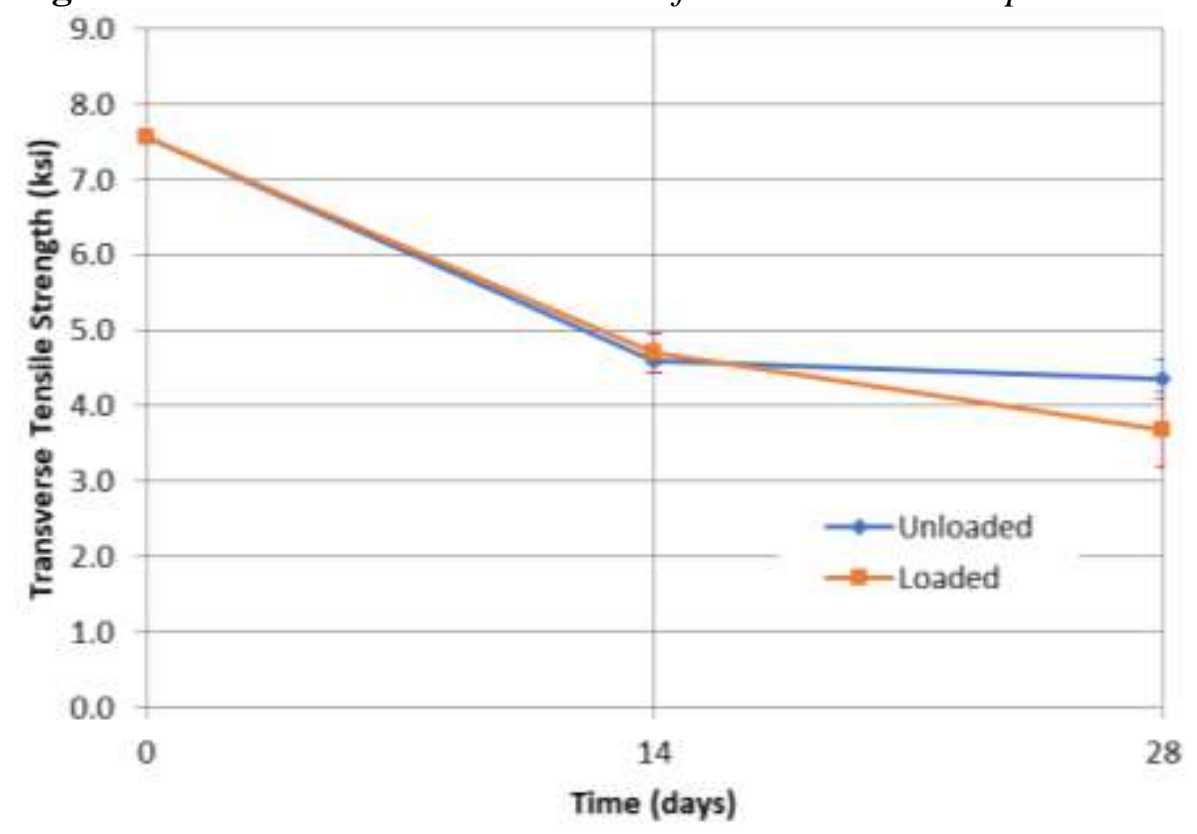

Transverse Modulus of Elasticity

Table 9 gives the experimental results for the environmentally conditioned preloaded specimens - in mega $\left(10^{6}\right)$ pounds per square inch; while Table 10 gives the experimental results for the initially unloaded specimens. In both cases, the results follow similar trends as transverse tensile strength and SBS test data. However, there are some changes in transverse tensile modulus; degradation is only observed for the specimens conditioned at $85^{\circ} \mathrm{C} / 93 \% \mathrm{RH}$. Some of the other specimens show an increase in properties. Also, note that no specimens were tested for the $85^{\circ} \mathrm{C} / 50 \% \mathrm{RH}$ case. There are no noticeable effects from 
stress conditioning; that is, the results for the preloaded and the initially unloaded cases are practically the same.

\section{High Temperature Data}

Additional testing was conducted to investigate the thermal degradation mechanism beyond post cure and is based on test matrix listed in Table 2 . The results presented in this section include specimens preloaded and initially unloaded at $100^{\circ} \mathrm{C}, 125^{\circ} \mathrm{C}$, and $150^{\circ} \mathrm{C}$ exposure conditions.

Table 9. Transverse Modulus (TTM) for Preloaded $\left[90^{\circ}\right]_{42}$ Specimens

\begin{tabular}{|c|c|c|c|c|c|c|c|c|c|c|c|c|}
\hline \multirow{3}{*}{$\begin{array}{c}\text { Time } \\
\text { (days) }\end{array}$} & \multicolumn{6}{|c|}{$40^{\circ} \mathrm{C}$ Exposure } & \multicolumn{6}{|c|}{$85^{\circ} \mathrm{C}$ Exposure } \\
\hline & \multicolumn{2}{|c|}{$2 \% \mathrm{RH}$} & \multicolumn{2}{|c|}{$50 \% \mathrm{RH}$} & \multicolumn{2}{|c|}{$93 \%$ RH } & \multicolumn{2}{|c|}{$2 \% \mathrm{RH}$} & \multicolumn{2}{|c|}{$50 \%$ RH } & \multicolumn{2}{|c|}{$93 \% \mathrm{RH}$} \\
\hline & $\begin{array}{l}\text { TTM } \\
\text { (msi) } \\
\end{array}$ & $\begin{array}{c}\text { SD } \\
\text { (msi) }\end{array}$ & $\begin{array}{l}\text { TTM } \\
(\mathrm{msi}) \\
\end{array}$ & $\begin{array}{c}\text { SD } \\
(\mathrm{msi}) \\
\end{array}$ & $\begin{array}{l}\text { TTM } \\
\text { (msi) } \\
\end{array}$ & $\begin{array}{c}\text { SD } \\
(\mathrm{msi})\end{array}$ & $\begin{array}{l}\text { TTM } \\
(\mathrm{msi}) \\
\end{array}$ & $\begin{array}{c}\text { SD } \\
(\mathrm{msi}) \\
\end{array}$ & $\begin{array}{l}\text { TTM } \\
(\mathrm{msi}) \\
\end{array}$ & $\begin{array}{c}\text { SD } \\
(\mathrm{msi})\end{array}$ & $\begin{array}{l}\text { TTM } \\
\text { (msi) } \\
\end{array}$ & $\begin{array}{r}\text { SD } \\
(\mathrm{msi}) \\
\end{array}$ \\
\hline 0 & 1.65 & 0.03 & 1.36 & 0.02 & 1.48 & 0.06 & 1.36 & 0.02 & 1.38 & 0.01 & 1.65 & 0.03 \\
\hline 14 & 1.66 & 0.04 & - & - & 1.61 & 0.02 & 1.68 & 0.06 & 1.31 & 0.02 & 1.66 & 0.04 \\
\hline 28 & 1.79 & 0.06 & 1.66 & 0.11 & 1.49 & 0.03 & 1.70 & 0.01 & 1.22 & 0.06 & 1.79 & 0.06 \\
\hline 35 & - & - & - & - & - & - & 1.75 & 0.05 & - & - & - & - \\
\hline 42 & 1.73 & 0.07 & 1.69 & 0.02 & 1.38 & 0.01 & - & - & - & - & 1.73 & 0.07 \\
\hline
\end{tabular}

Table 10. Transverse Modulus (TTM) for Unloaded $\left[90^{\circ}\right]_{42}$ Specimens

\begin{tabular}{|c|c|c|c|c|c|c|c|c|c|c|c|c|}
\hline \multirow{3}{*}{$\begin{array}{l}\text { Time } \\
\text { (days) }\end{array}$} & \multicolumn{6}{|c|}{$40^{\circ} \mathrm{C}$ Exposure } & \multicolumn{6}{|c|}{$85^{\circ} \mathrm{C}$ Exposure } \\
\hline & \multicolumn{2}{|c|}{$2 \% \mathrm{RH}$} & \multicolumn{2}{|c|}{$50 \% \mathrm{RH}$} & \multicolumn{2}{|c|}{$93 \% \mathrm{RH}$} & \multicolumn{2}{|c|}{$2 \% \mathrm{RH}$} & \multicolumn{2}{|c|}{$50 \% \mathrm{RH}$} & \multicolumn{2}{|c|}{$93 \% \mathrm{RH}$} \\
\hline & $\begin{array}{l}\text { TTM } \\
\text { (msi) }\end{array}$ & $\begin{array}{c}\text { SD } \\
(\mathrm{msi})\end{array}$ & $\begin{array}{l}\text { TTM } \\
(\mathrm{msi})\end{array}$ & $\begin{array}{c}\mathrm{SD} \\
(\mathrm{msi})\end{array}$ & $\begin{array}{l}\text { TTM } \\
\text { (msi) }\end{array}$ & $\begin{array}{c}\mathrm{SD} \\
(\mathrm{msi})\end{array}$ & $\begin{array}{l}\text { TTM } \\
\text { (msi) }\end{array}$ & $\begin{array}{c}\mathrm{SD} \\
(\mathrm{msi})\end{array}$ & $\begin{array}{l}\text { TTM } \\
\text { (msi) }\end{array}$ & $\begin{array}{c}\text { SD } \\
(\mathrm{msi})\end{array}$ & $\begin{array}{l}\text { TTM } \\
\text { (msi) }\end{array}$ & $\underset{(\mathrm{msi})}{\mathrm{SD}}$ \\
\hline 0 & 1.65 & 0.31 & 1.42 & 0.07 & 1.53 & 0.05 & 1.38 & 0.01 & 1.38 & 0.01 & 1.65 & 0.31 \\
\hline 14 & - & - & $1.70^{\mathrm{a}}$ & - & 1.42 & 0.03 & 1.65 & 0.04 & - & - & - & - \\
\hline 28 & 1.73 & 0.01 & 1.55 & 0.06 & 1.45 & 0.02 & 1.66 & 0.03 & 1.23 & 0.00 & 1.73 & 0.01 \\
\hline 35 & - & - & - & - & - & - & 1.76 & 0.05 & - & - & - & - \\
\hline 42 & 1.70 & 0.03 & 1.64 & 0.05 & 1.63 & 0.02 & - & - & - & - & 1.70 & 0.03 \\
\hline
\end{tabular}

a only one data point for this case because no strains were recorded.

\section{$\underline{\text { Baseline Data }}$}

The baseline data for the longitudinal tensile properties are listed in each table for time equals zero days. For cases where multiple panels were used in a single data set, the baseline values were obtained by averaging values of corresponding panels. The baseline results for the inter-laminar shear and transverse tensile strength are obtained from only one 42-ply panel. This panel had 7,160 psi inter-laminar shear strength and 200 psi standard deviation and 8,517 psi transverse tensile strength and 314 psi standard deviation. The 8,517psi transverse tensile strength was used to obtain the load for stress conditioning, which for this case was 80 pounds.

\section{Inter-laminar Shear Strength, SBS Tests Results}

Table 11 lists the inter-laminar shear strength degradation data for the SBS tests for exposure temperatures of $100^{\circ} \mathrm{C}, 125^{\circ} \mathrm{C}$, and $150^{\circ} \mathrm{C}$; unloaded initially 
and preloaded with 80 pounds. It was expected that all three temperature conditions would show a steady increase in properties as post curing occurred. However, the $100^{\circ} \mathrm{C}$ and $125^{\circ} \mathrm{C}$ preloaded, and the $100^{\circ} \mathrm{C}$ initially unloaded cases show an initial slight decrease in strength, followed by what appears to be an eventual post curing strengthening. The higher temperature cases all show an increase in strength followed by what appears to be an eventual degradation as shown in Figure 5.

Table 11. ILSS of High Temperature Conditioned Specimens

\begin{tabular}{|c|c|c|c|c|c|c|c|c|c|c|c|c|}
\hline \multirow{3}{*}{$\begin{array}{c}\text { Time } \\
(\text { days })\end{array}$} & \multicolumn{6}{|c|}{ Preloaded with $80 \mathrm{lbs}$} & \multicolumn{6}{|c|}{ Unloaded } \\
\hline & \multicolumn{2}{|c|}{$100^{\circ} \mathrm{C}$} & \multicolumn{2}{|c|}{$125^{\circ} \mathrm{C}$} & \multicolumn{2}{|c|}{$150^{\circ} \mathrm{C}$} & \multicolumn{2}{|c|}{$100^{\circ} \mathrm{C}$} & \multicolumn{2}{|c|}{$125^{\circ} \mathrm{C}$} & \multicolumn{2}{|c|}{$150^{\circ} \mathrm{C}$} \\
\hline & $\begin{array}{c}\text { ILSS } \\
\text { (ksi) }\end{array}$ & $\begin{array}{c}\text { SD } \\
\text { (ksi) }\end{array}$ & $\begin{array}{l}\text { ILSS } \\
\text { (ksi) }\end{array}$ & $\begin{array}{c}\text { SD } \\
\text { (ksi) }\end{array}$ & $\begin{array}{c}\text { ILSS } \\
\text { (ksi) }\end{array}$ & $\begin{array}{c}\text { SD } \\
\text { (ksi) }\end{array}$ & $\begin{array}{r}\text { ILSS } \\
\text { (ksi) }\end{array}$ & $\begin{array}{c}\text { SD } \\
\text { (ksi) }\end{array}$ & $\begin{array}{r}\text { ILSS } \\
\text { (ksi) }\end{array}$ & $\begin{array}{l}\text { SD } \\
\text { (ksi) }\end{array}$ & $\begin{array}{r}\text { ILSS } \\
\text { (ksi) }\end{array}$ & $\begin{array}{c}\text { SD } \\
(\mathrm{ksi})\end{array}$ \\
\hline 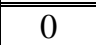 & 7.16 & 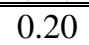 & $\overline{7.16}$ & $\overline{0.20}$ & $\begin{array}{c}7.16 \\
\end{array}$ & $\overline{0.20}$ & 7.16 & $\overline{0.20}$ & $\overline{77.16}$ & 0.20 & $\overline{77.16}$ & $\overline{0.20}$ \\
\hline 3 & - & - & - & - & 7.76 & 0.15 & - & 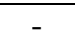 & - & & 8.59 & 0.14 \\
\hline 4 & 7.09 & 0.28 & 6.52 & 0.10 & - & - & 6.47 & 0.17 & 7.80 & 0.14 & - & - \\
\hline 7 & 7.54 & 0.21 & - & - & 7.65 & 0.19 & 7.11 & 0.10 & - & - & 8.56 & 0.17 \\
\hline 8 & - & - & 7.27 & 0.21 & - & - & - & - & 7.57 & 0.11 & - & - \\
\hline 11 & 7.22 & 0.21 & - & - & - & - & 7.21 & 0.16 & - & - & 7.97 & 0.16 \\
\hline 13 & - & - & 7.33 & 0.23 & 7.11 & 0.25 & - & - & 7.10 & 0.18 & - & - \\
\hline
\end{tabular}

Figure 5. Preloaded vs. Unloaded ILSS from SBS Test for $150^{\circ} \mathrm{C}$

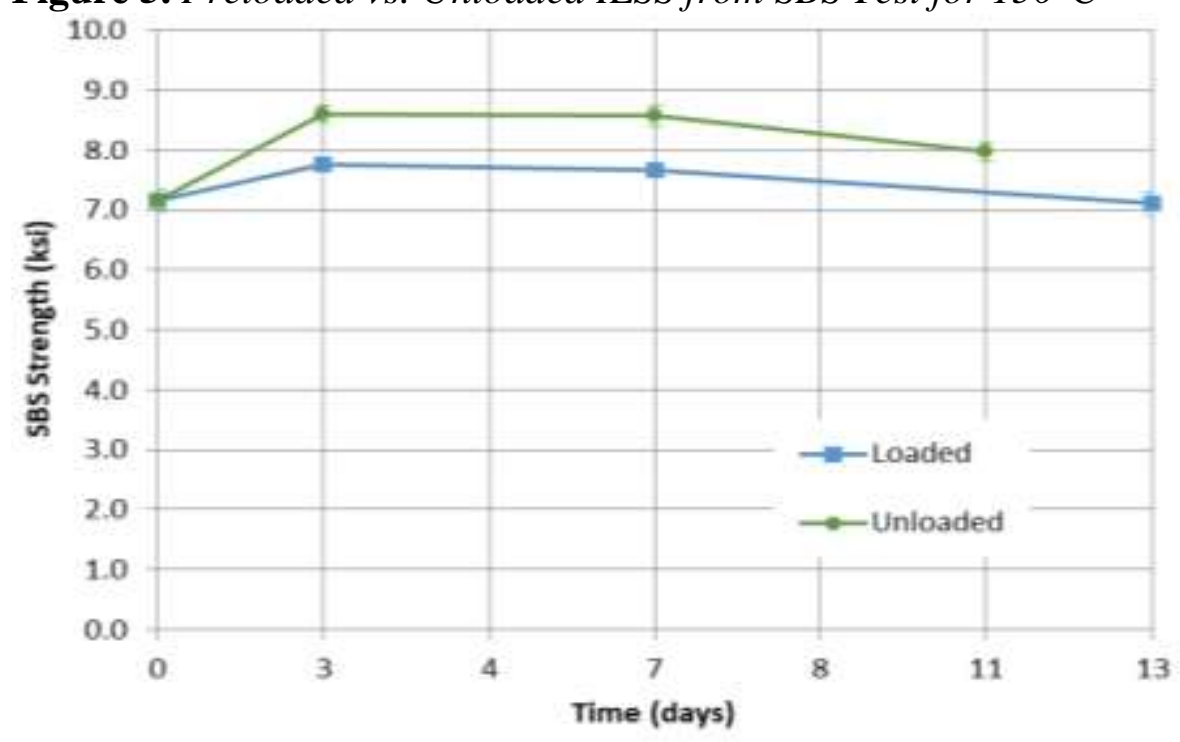

$\underline{\text { Tensile Tests Results }}$

The material properties used to investigate the effect of high temperature exposure conditions on composites were the longitudinal strength, longitudinal modulus of elasticity, and major Poison's ration. Each set of three properties was obtained from the same tensile test; tensile strength is based on breaking load, the modulus of elasticity is the slope of the stress-strain diagram, and the Poison's ratio is obtained from the longitudinal and transverse strains. 


\section{Longitudinal Tensile Strength}

Table 12 gives the longitudinal tensile strength (with heading of $\mathrm{X}$ in the table) data for exposure temperatures of $100^{\circ} \mathrm{C}, 125^{\circ} \mathrm{C}$, and $150^{\circ} \mathrm{C}$, initially unloaded and preloaded with 80 pounds. This data follows similar trends as the SBS tests data, with some minor differences. It was expected that all three conditions would show a steady increase in properties as post curing occurred. However, all $100^{\circ} \mathrm{C}$ and $125^{\circ} \mathrm{C}$ cases show an initial slight decrease in strength, followed by an eventual post-cure strengthening.

Table 12. Longitudinal Tensile Strength (LTS) of $\left[0^{\circ}\right]_{10}$ Layup Specimens

\begin{tabular}{|c|c|c|c|c|c|c|c|c|c|c|c|c|}
\hline \multirow{3}{*}{$\begin{array}{l}\text { Time } \\
\text { (days) }\end{array}$} & \multicolumn{6}{|c|}{ Preloaded with $80 \mathrm{lbs}$} & \multicolumn{6}{|c|}{ Unloaded } \\
\hline & \multicolumn{2}{|c|}{$100^{\circ} \mathrm{C}$} & \multicolumn{2}{|c|}{$125^{\circ} \mathrm{C}$} & \multicolumn{2}{|c|}{$150^{\circ} \mathrm{C}$} & \multicolumn{2}{|c|}{$100^{\circ} \mathrm{C}$} & \multicolumn{2}{|c|}{$125^{\circ} \mathrm{C}$} & \multicolumn{2}{|c|}{$150^{\circ} \mathrm{C}$} \\
\hline & $\begin{array}{c}\text { LTS } \\
\text { (ksi) }\end{array}$ & $\begin{array}{c}\mathrm{SD} \\
\text { (ksi) }\end{array}$ & $\begin{array}{c}\text { LTS } \\
(\mathrm{ksi})\end{array}$ & $\begin{array}{c}\mathrm{SD} \\
\text { (ksi) }\end{array}$ & $\begin{array}{c}\text { LTS } \\
(\mathrm{ksi})\end{array}$ & $\begin{array}{c}\mathrm{SD} \\
(\mathrm{ksi})\end{array}$ & $\begin{array}{l}\text { LTS } \\
\text { (ksi) }\end{array}$ & $\begin{array}{c}\mathrm{SD} \\
\text { (ksi) }\end{array}$ & $\begin{array}{c}\text { LTS } \\
(\mathrm{ksi})\end{array}$ & $\begin{array}{c}\mathrm{SD} \\
\text { (ksi) }\end{array}$ & $\begin{array}{c}\text { LTS } \\
(\mathrm{ksi})\end{array}$ & $\begin{array}{c}\mathrm{SD} \\
\text { (ksi) }\end{array}$ \\
\hline 0 & 116 & 2.7 & 126 & 9.2 & 117 & 15.9 & 116 & 2.7 & 126 & 9.2 & 117 & 15.9 \\
\hline 3 & - & - & - & - & 116 & 15.0 & - & - & - & - & 125 & 3.1 \\
\hline 4 & 117 & 15.1 & 105 & 19.2 & - & - & 88 & 1.1 & 131 & 5.5 & - & - \\
\hline 7 & 105 & 12.1 & - & - & 121 & 5.2 & 102 & 0.8 & - & - & 114 & 13.1 \\
\hline 8 & - & - & 85 & 7.9 & - & - & - & - & 117 & 3.9 & - & - \\
\hline 11 & 104 & 15.6 & - & - & 120 & 10.3 & 95 & 23.4 & - & - & 119 & 5.9 \\
\hline 13 & - & - & 91 & 17.5 & - & - & - & - & 117 & 15.8 & - & - \\
\hline
\end{tabular}

The higher temperature cases show a slight increase in strength as shown in Figure 6. This plot shows the effect of stress conditioning, and clearly shows that preloading has little effect on longitudinal tensile strength at high temperatures. This is reasonable considering that degradation is experienced primarily by the matrix material and not the fibers, which dominate the longitudinal properties.

Figure 6. Preloaded vs. Unloaded Longitudinal Tensile Strength for $150^{\circ} \mathrm{C}$

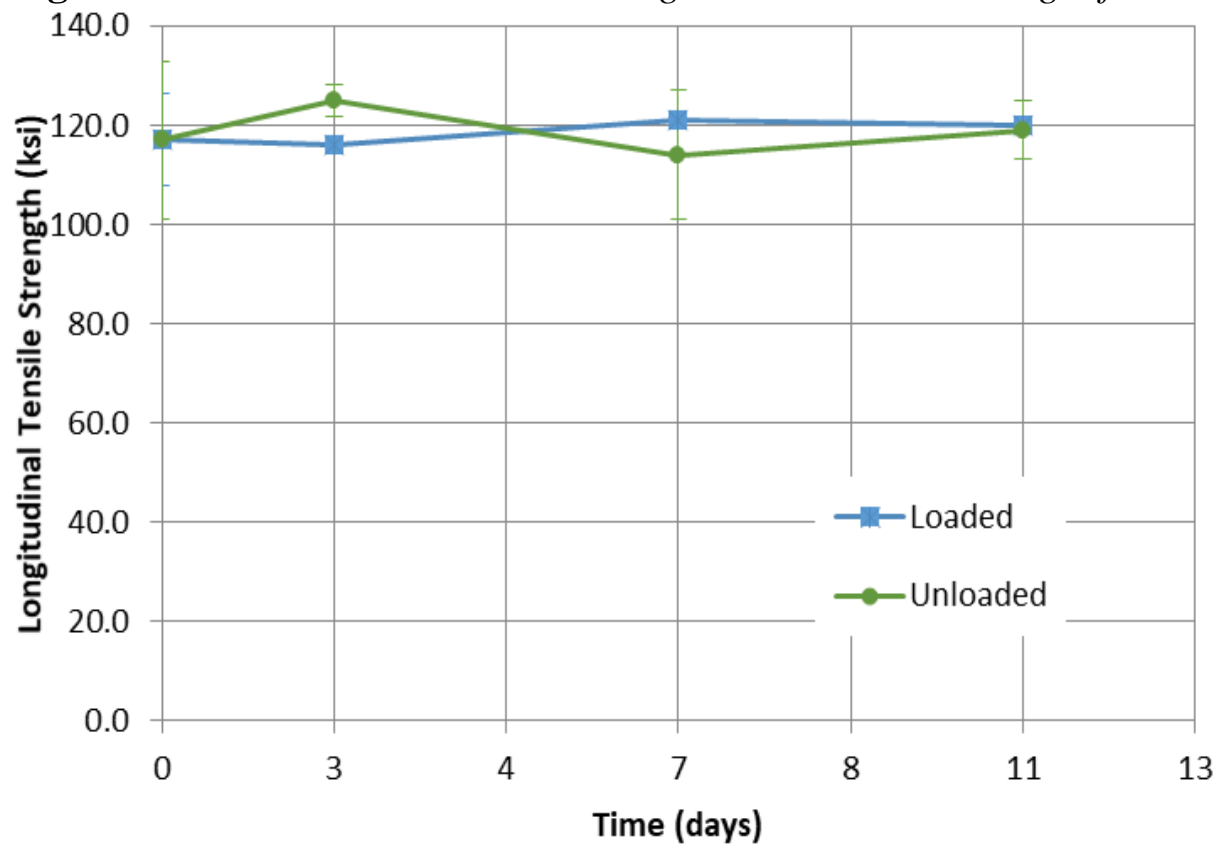




\section{Longitudinal Modulus of Elasticity}

Table 13 gives the longitudinal modulus of elasticity data for exposure temperature of $100^{\circ} \mathrm{C}, 125^{\circ} \mathrm{C}$, and $150^{\circ} \mathrm{C}$, preloaded and initially unloaded. This data follows similar trends as the SBS tests and tensile strength data, with some minor differences. There appears to be minor stiffness degradation for some of the conditions.

Table 13. Longitudinal Tensile Modulus (E) of $\left[0^{\circ}\right]_{10}$ Layup Specimens

\begin{tabular}{|c|c|c|c|c|c|c|c|c|c|c|c|c|}
\hline \multirow{3}{*}{$\begin{array}{c}\text { Time } \\
\text { (days) }\end{array}$} & \multicolumn{6}{|c|}{ Preloaded with $80 \mathrm{lbs}$} & \multicolumn{6}{|c|}{ Unloaded } \\
\hline & \multicolumn{2}{|c|}{$100^{\circ} \mathrm{C}$} & \multicolumn{2}{|c|}{$125^{\circ} \mathrm{C}$} & \multicolumn{2}{|c|}{$150^{\circ} \mathrm{C}$} & \multicolumn{2}{|c|}{$100^{\circ} \mathrm{C}$} & \multicolumn{2}{|c|}{$125^{\circ} \mathrm{C}$} & \multicolumn{2}{|c|}{$150^{\circ} \mathrm{C}$} \\
\hline & $\underset{(\mathrm{msi})}{\mathrm{E}}$ & $\begin{array}{c}\text { SD } \\
(\mathrm{msi})\end{array}$ & $\underset{(\mathrm{msi})}{\mathrm{E}}$ & $\begin{array}{c}\text { SD } \\
(\mathrm{msi})\end{array}$ & $\underset{(\mathrm{msi})}{\mathrm{E}}$ & $\begin{array}{c}\text { SD } \\
(\mathrm{msi})\end{array}$ & $\underset{(\mathrm{msi})}{\mathrm{E}}$ & $\begin{array}{l}\text { SD } \\
\text { (msi) }\end{array}$ & $\underset{(\mathrm{msi})}{\mathrm{E}}$ & $\begin{array}{c}\text { SD } \\
(\mathrm{msi})\end{array}$ & $\underset{(\mathrm{msi})}{\mathrm{E}}$ & $\begin{array}{c}\text { SD } \\
(\mathrm{msi})\end{array}$ \\
\hline 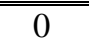 & 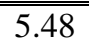 & 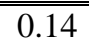 & 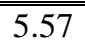 & 0.37 & $\overline{c 5.71}$ & 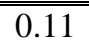 & 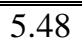 & $\overline{0.14}$ & 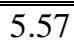 & 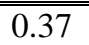 & 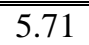 & 0.11 \\
\hline 3 & - & - & - & - & 5.74 & 0.15 & - & - & - & - & 5.83 & 0.04 \\
\hline 4 & 5.82 & 0.16 & 5.43 & 0.10 & - & 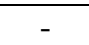 & 5.75 & 0.12 & 5.78 & 0.27 & - & - \\
\hline 7 & 5.84 & 0.06 & - & - & 5.63 & 0.32 & 5.59 & 0.27 & - & - & 5.70 & 0.12 \\
\hline 8 & - & - & 5.18 & 0.16 & - & - & - & - & 5.55 & 0.20 & - & - \\
\hline 11 & 5.61 & 0.26 & - & - & 5.60 & 0.13 & 5.34 & 0.28 & - & - & 5.61 & 0.19 \\
\hline 13 & - & - & 5.62 & 0.09 & - & - & - & - & 5.71 & 0.13 & - & - \\
\hline
\end{tabular}

\section{Major Poison's Ratio}

Table 14 gives the major Poisson's ratio data for exposure temperature of $100^{\circ} \mathrm{C}, 125^{\circ} \mathrm{C}$, and $150^{\circ} \mathrm{C}$, preloaded and initially unloaded. This data shows little or no change.

Table 14. Major Poisson's Ratio(nu) of $\left[0^{\circ}\right]_{10}$ Layup Specimens

\begin{tabular}{|c|c|c|c|c|c|c|c|c|c|c|c|c|}
\hline \multirow{3}{*}{$\begin{array}{l}\text { Time } \\
\text { (days) }\end{array}$} & \multicolumn{6}{|c|}{ Preloaded with $80 \mathrm{lbs}$} & \multicolumn{6}{|c|}{ Unloaded } \\
\hline & \multicolumn{2}{|c|}{$100^{\circ} \mathrm{C}$} & \multicolumn{2}{|c|}{$125^{\circ} \mathrm{C}$} & \multicolumn{2}{|c|}{$150^{\circ} \mathrm{C}$} & \multicolumn{2}{|c|}{$100^{\circ} \mathrm{C}$} & \multicolumn{2}{|c|}{$125^{\circ} \mathrm{C}$} & \multicolumn{2}{|c|}{$150^{\circ} \mathrm{C}$} \\
\hline & $\mathrm{nu}$ & SD & $\mathrm{nu}$ & SD & nu & SD & nu & SD & $\mathrm{nu}$ & SD & nu & SD \\
\hline 0 & 0.237 & 0.005 & 0.243 & 0.018 & 0.244 & 0.006 & 0.237 & 0.005 & 0.243 & 0.018 & 0.244 & 0.006 \\
\hline J & & & & & 0.234 & 0.005 & & & - & & 0.237 & 0.004 \\
\hline 4 & 0.246 & 005 & 234 & .012 & & - & 0.236 & 012 & 237 & 0.023 & & - \\
\hline 7 & 0.235 & 0.006 & & - & 0.244 & 0.012 & 0.237 & 0.005 & - & & 0.231 & 0.002 \\
\hline 8 & & - & 0.245 & 0.006 & & & & - & 0.230 & 0.008 & & - \\
\hline 11 & .248 & 025 & & - & 0.226 & 0.00 & 0.241 & 0.017 & & 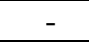 & .234 & 0.005 \\
\hline 13 & - & - & 0.242 & 0.001 & & & & - & 0.242 & 0.016 & & - \\
\hline
\end{tabular}

\section{Model Prediction Data}

Based on the results of all the tests presented thus far, further efforts were focused on the hygro-thermal degradation mechanisms, which include thermal post-curing and hygro-thermal degradation. The post-curing mechanism is a thermally-driven reaction that generally causes an improvement in matrix properties; while the hygro-thermal degradation mechanism is a coupled temperature and moisture driven reaction that is destructive to the matrix material and causes degradation of properties. The environmental conditions for the samples for this set of tests were dry at $125^{\circ} \mathrm{C}$ (for post-curing) and $50 \% \mathrm{RH}$ at 
$85^{\circ} \mathrm{C}$ (for hygro-thermal), stressed and unstressed. Also, to obtain data that can be used to verify more complex layups the samples were fabricated using a quasiisotropic layup.

\section{$\underline{\text { Baseline Data }}$}

The baseline data for the longitudinal tensile properties of both $\left[0^{\circ}\right]_{10}$ and quasi-isotropic layupsis listed in each table for time equals zero days. For cases where multiple panels were used in a single data set, the baseline values were obtained by averaging values of corresponding panels. The baseline results for the inter-laminar shear strength are obtained from only one 42-ply panel. This panel had 7,146 psi with SD of 280 psi.

It was noted earlier that all panels (including the $\left[0^{\circ}\right]_{10}$ and quasi-isotropic) were cut into 11 " by 1 " coupons. The SBS coupons were cut into five smaller pieces, while the tension ones were full size, 11 " by 1 ". The tensile specimens were used to obtain longitudinal properties (which were obtained from stressstrain diagrams) and Poison's ratio.

\section{Inter-laminar Shear Strength, SBS Tests Results}

The inter-laminar shear strength degradation data for the SBS tests from the two exposure conditions is given in Table 15; initially unloaded and preloaded with 40 pounds. As expected, the dry, $125^{\circ} \mathrm{C}$ cases show a steady increase in properties as post curing occurred. The higher temperature cases all show an increase in strength followed by what appears to be an eventual degradation as shown in Figure 7.

Table 15. ILSS of Hygro-thermal Degradation Specimens

\begin{tabular}{|c|c|c|c|c|c|c|c|c|c|}
\hline \multirow{3}{*}{$\begin{array}{c}\text { Time } \\
\text { (days) }\end{array}$} & \multicolumn{4}{|c|}{$50 \% \mathrm{RH}$ at $85^{\circ} \mathrm{C}$} & \multirow{3}{*}{$\begin{array}{l}\text { Time } \\
\text { (days) }\end{array}$} & \multicolumn{4}{|c|}{ Dry at $125^{\circ} \mathrm{C}$} \\
\hline & \multicolumn{2}{|c|}{ Loaded } & \multicolumn{2}{|c|}{ Unloaded } & & \multicolumn{2}{|c|}{ Loaded } & \multicolumn{2}{|c|}{ Unloaded } \\
\hline & $\begin{array}{l}\text { ILSS } \\
\text { (ksi) }\end{array}$ & $\begin{array}{c}\text { SD } \\
\text { (ksi) }\end{array}$ & $\begin{array}{c}\text { ILSS } \\
\text { (ksi) }\end{array}$ & $\begin{array}{c}\text { SD } \\
\text { (ksi) }\end{array}$ & & $\begin{array}{c}\text { ILSS } \\
\text { (ksi) }\end{array}$ & $\begin{array}{c}\text { SD } \\
\text { (ksi) }\end{array}$ & $\begin{array}{l}\text { ILSS } \\
(\mathrm{ksi})\end{array}$ & $\begin{array}{c}\text { SD } \\
\text { (ksi) }\end{array}$ \\
\hline 0 & 7.15 & 0.280 & 7.15 & 0.280 & 0 & 7.15 & 0.280 & 7.15 & 0.280 \\
\hline 14 & 6.04 & 0.073 & 6.87 & 0.209 & 7 & 8.36 & 0.283 & 8.38 & 0.241 \\
\hline 28 & 5.78 & 0.134 & 5.22 & 0.081 & 14 & 8.42 & 0.244 & 7.60 & 0.197 \\
\hline 42 & 5.39 & 0.173 & 5.02 & 0.102 & 21 & 8.49 & 0.168 & 8.64 & 0.283 \\
\hline
\end{tabular}


Figure 7. Preloaded vs. Unloaded ILSS Strength for $50 \%$ RH at $85^{\circ} \mathrm{C}$

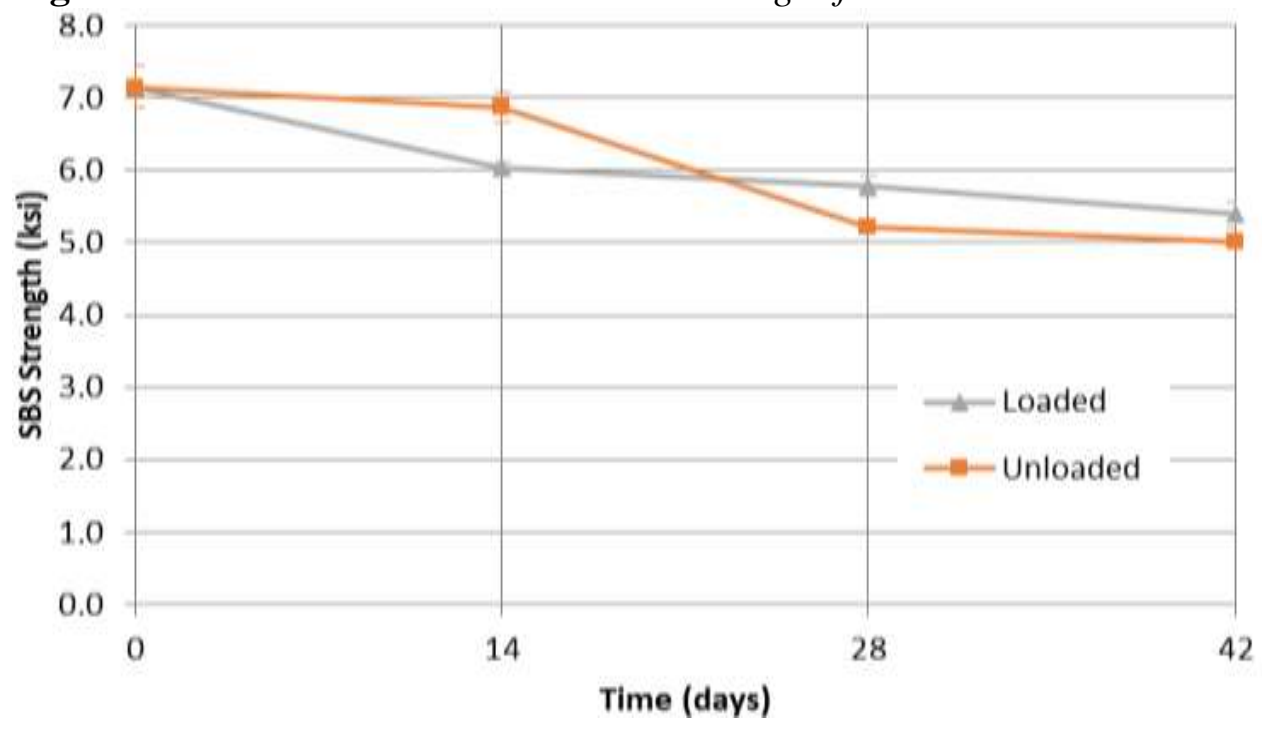

\section{$\underline{\text { Tensile Tests Results }}$}

The material properties derived from tensile tests include the ultimate longitudinal tensile strength, the longitudinal tensile modulus of elasticity, and the Poison's ratio. These properties were collected for the unidirectional and quasi-isotropic layups, all of which were unloaded. The degradation data for the two exposure conditions is given in Table 16 for the ultimate longitudinal tensile strength, in Table 17 for the longitudinal tensile modulus, and in Table 18 for the major Poison's ratio. Notice that there is a substantial degradation in properties of both $\left[0^{\circ}\right]_{10}$ and quasi-isotropic specimens for the $50 \% \mathrm{RH}$ at $85^{\circ} \mathrm{C}$ initially, but no appreciable change for the dry at $125^{\circ} \mathrm{C}$ specimens; see Figures 7 and 8. However, there is no appreciable degradation in modulus or Poisson's ratio properties.

Table 16. Longitudinal Tensile Strength (LTS) of $\left[0^{\circ}\right]_{10}$ \& Quasi-isotropic Specimens

\begin{tabular}{|c|c|c|c|c|c|c|c|c|}
\hline \multirow{3}{*}{$\begin{array}{c}\text { Time } \\
\text { (days) }\end{array}$} & \multicolumn{4}{|c|}{ Unidirectional } & \multicolumn{4}{|c|}{ Quasi-isotropic } \\
\hline & \multicolumn{2}{|c|}{$50 \% \mathrm{RH}$ at $85^{\circ} \mathrm{C}$} & \multicolumn{2}{|c|}{ Dry at $125^{\circ} \mathrm{C}$} & \multicolumn{2}{|c|}{$50 \%$ RH at $85^{\circ} \mathrm{C}$} & \multicolumn{2}{|c|}{ Dry at $125^{\circ} \mathrm{C}$} \\
\hline & $\begin{array}{c}\text { LTS } \\
(\mathrm{ksi})\end{array}$ & $\begin{array}{c}\text { SD } \\
(\mathrm{ksi})\end{array}$ & $\begin{array}{l}\text { LTS } \\
(\mathrm{ksi})\end{array}$ & $\begin{array}{c}\text { SD } \\
\text { (ksi) }\end{array}$ & $\begin{array}{l}\text { LTS } \\
\text { (ksi) }\end{array}$ & $\begin{array}{c}\mathrm{SD} \\
(\mathrm{ksi})\end{array}$ & $\begin{array}{l}\text { LTS } \\
\text { (ksi) }\end{array}$ & $\begin{array}{c}\mathrm{SD} \\
(\mathrm{ksi})\end{array}$ \\
\hline$\overline{0}$ & 121.2 & 13.1 & 121.2 & $\overline{13.1}$ & 40.3 & 4.30 & 41.4 & 2.34 \\
\hline 7 & - & - & 119 & 5.88 & - & - & 42.0 & 4.05 \\
\hline 14 & 60.6 & 6.36 & 116 & 11.1 & 23.6 & 1.25 & 40.9 & 3.33 \\
\hline 21 & - & - & 119 & 5.45 & - & - & 40.1 & 3.89 \\
\hline 28 & 63.3 & 3.97 & - & - & 23.9 & 1.05 & - & - \\
\hline 42 & 64.6 & 3.16 & - & - & 23.0 & 1.68 & - & - \\
\hline
\end{tabular}


Table 17. Longitudinal Modulus (E) of $\left[0^{\circ}\right]_{10}$ and Quasi-isotropic Specimens

\begin{tabular}{|c|c|c|c|c|c|c|c|c|}
\hline \multirow{3}{*}{$\begin{array}{c}\text { Time } \\
\text { (days) }\end{array}$} & \multicolumn{4}{|c|}{ Unidirectional } & \multicolumn{4}{|c|}{ Quasi-isotropic } \\
\hline & \multicolumn{2}{|c|}{$50 \% \mathrm{RH}$ at $85^{\circ} \mathrm{C}$} & \multicolumn{2}{|c|}{ Dry at $125^{\circ} \mathrm{C}$} & \multicolumn{2}{|c|}{$50 \% \mathrm{RH}$ at $85^{\circ} \mathrm{C}$} & \multicolumn{2}{|c|}{ Dry at $125^{\circ} \mathrm{C}$} \\
\hline & $\mathrm{E}(\mathrm{msi})$ & $\begin{array}{l}\text { SD } \\
(\mathrm{msi})\end{array}$ & $\mathrm{E}(\mathrm{msi})$ & $\begin{array}{c}\text { SD } \\
(\mathrm{msi})\end{array}$ & $\mathrm{E}(\mathrm{msi})$ & $\begin{array}{c}\mathrm{SD} \\
(\mathrm{msi})\end{array}$ & $\begin{array}{c}E \\
(\mathrm{msi})\end{array}$ & $\begin{array}{c}\text { SD } \\
(\mathrm{msi})\end{array}$ \\
\hline 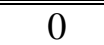 & 5.86 & 0.205 & 5.86 & 0.205 & 2.44 & 0.142 & 2.53 & 0.078 \\
\hline 7 & - & - & 5.43 & 0.193 & - & - & 2.43 & 0.019 \\
\hline 14 & 5.06 & 0.092 & 5.49 & 0.212 & 2.33 & 0.055 & 2.36 & 0.039 \\
\hline 21 & - & - & 5.70 & 0.155 & - & - & 2.57 & 0.038 \\
\hline 28 & 5.68 & 0.226 & - & - & 2.29 & 0.033 & - & - \\
\hline 42 & 5.64 & 0.285 & - & - & 2.22 & 0.048 & - & - \\
\hline
\end{tabular}

Table 18. Poisson's Ratio (nu) of $\left[0^{\circ}\right]_{10}$ and Quasi-isotropic Specimens

\begin{tabular}{|c|c|c|c|c|c|c|c|c|}
\hline \multirow{3}{*}{$\begin{array}{l}\text { Time } \\
\text { (days) }\end{array}$} & \multicolumn{4}{|c|}{ Unidirectional } & \multicolumn{4}{|c|}{ Quasi-isotropic } \\
\hline & \multicolumn{2}{|c|}{$50 \% \mathrm{RH}$ at $85^{\circ} \mathrm{C}$} & \multicolumn{2}{|c|}{ Dry at $125^{\circ} \mathrm{C}$} & \multicolumn{2}{|c|}{$50 \% \mathrm{RH}$ at $85^{\circ} \mathrm{C}$} & \multicolumn{2}{|c|}{ Dry at $125^{\circ} \mathrm{C}$} \\
\hline & nu & SD & $\mathrm{nu}$ & SD & nu & SD & nu & SD \\
\hline 0 & 0.236 & 0.009 & 0.236 & 0.009 & 0.307 & 0.018 & 0.298 & 0.024 \\
\hline 7 & - & - & 0.220 & 0.009 & - & - & 0.277 & 0.010 \\
\hline 14 & 0.220 & 0.012 & 0.221 & 0.003 & 0.337 & 0.010 & 0.272 & 0.015 \\
\hline 21 & - & - & 0.215 & 0.028 & - & - & 0.308 & 0.012 \\
\hline 28 & 0.239 & 0.014 & - & - & 0.313 & 0.014 & - & - \\
\hline 42 & 0.228 & 0.013 & - & - & 0.299 & 0.012 & - & - \\
\hline
\end{tabular}

\section{Conclusions}

The preliminary data results indicate that the time to convergence of the tested properties did primarily depended on the environmental conditioning temperature - as the temperature increased, the time to convergence of the tested properties decreased. Materials generally only experienced degradation for the specimens conditioned at $85^{\circ} \mathrm{C} / 93 \% \mathrm{RH}$, which is associated with a hygrothermal degradation mechanism. This is primarily driven by the presence of moisture and tends to decrease (or degrade) the matrix properties with time. Second, the effect of temperature appears to initially increase the inter-laminar shear strength, which is likely due to post curing of the epoxy matrix at temperatures above room temperature. 
Figure 7. Longitudinal Strength of $\left[0^{\circ}\right]_{10}$ Specimens for $50 \% \mathrm{RH}$ at $85^{\circ} \mathrm{C}$ and Dry at $125^{\circ} \mathrm{C}$

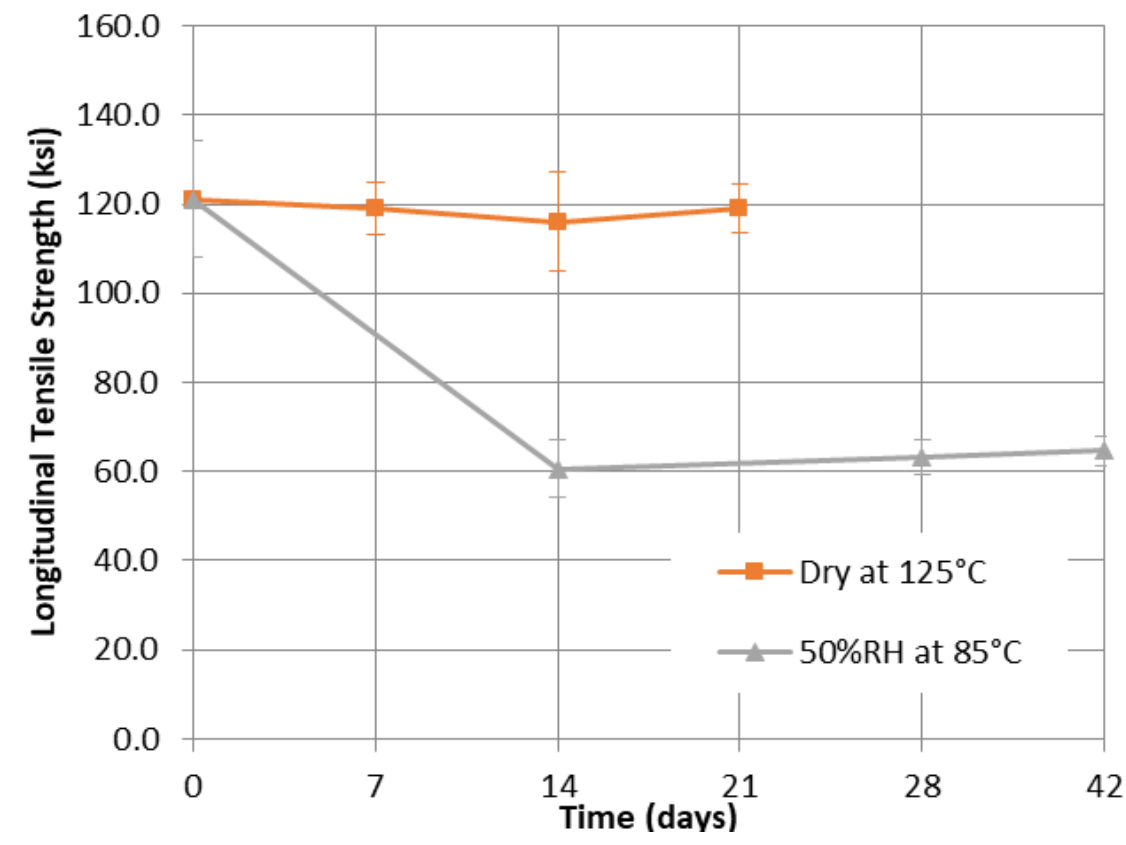

Figure 8. Longitudinal Strength of Quasi-isotropic Specimens for 50\% RH at $85^{\circ} \mathrm{C}$ and Dry at $125^{\circ} \mathrm{C}$

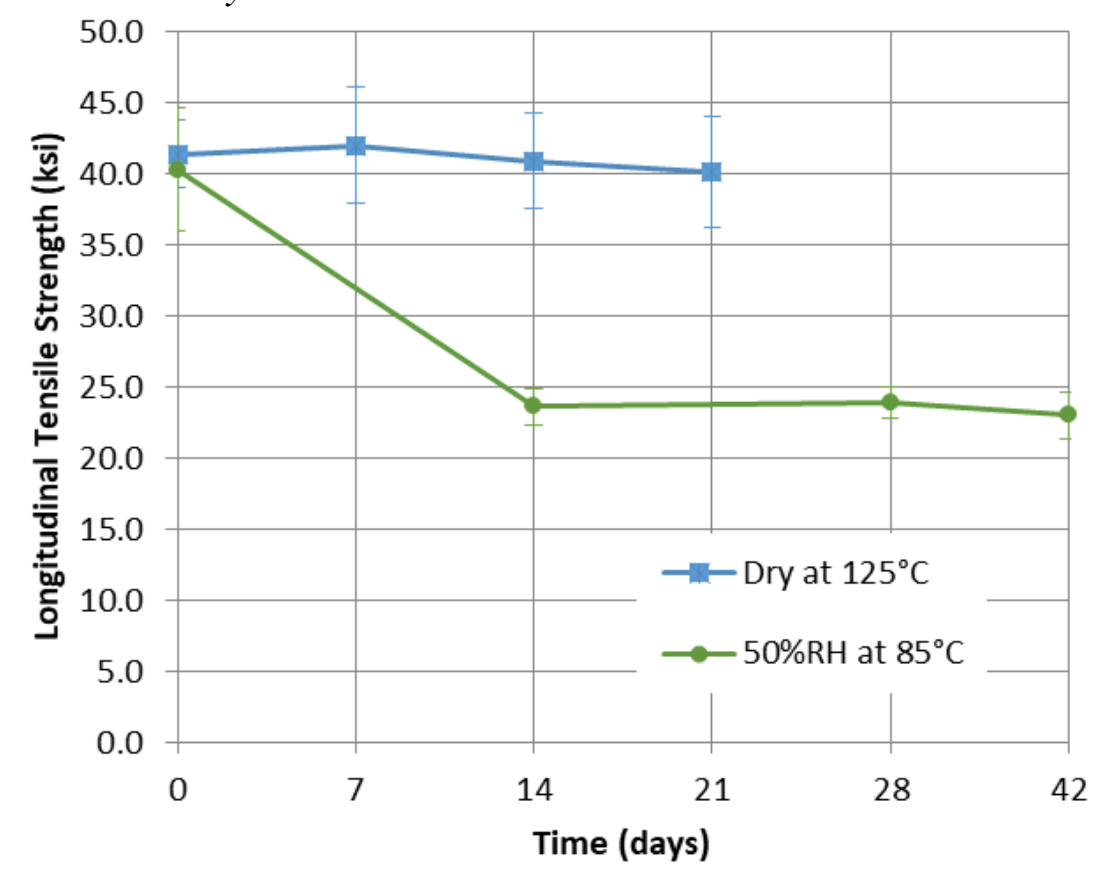

This shows that properties dominated by the matrix are most affected by the effects of moisture and temperature. Based on the results, two primary degradation mechanisms were identified: 
1. Post-curing, which is a thermally-driven reaction that causes an increase in matrix properties

2. Hygro-thermal degradation, which is dependent on temperature and moisture levels, and is destructive to the matrix material

The set of tests that was conducted at high temperatures to isolate thermal effects on composites did not result in significant degradation; in fact, it appears that there is an increase in propertied, which can be attributed to post curing. Finally, preloading the specimens with $2 \%$ of the strength resulted in some degradation in propertied for most cases as shown in the figures; particularly for the higher temperature and moisture conditions. This degradation may be the result of creating more voids as the specimens are stretched and additional moisture ingress into the material, causing further degradation of the matrix material.

\section{References}

Arhant, M., Le Gac, P.Y., LeGall, M., Burtin, C., Briancon, C., and Davies, P. "Effect of sea water and humidity on the tensile and compressive properties of carbonpolyamide 6 laminates", Composites Part A: Applied Science and Manufacturing, Volume 91, December 2016, p. 250-261. Elsevier.

ASTM D2334.Standard Test Method for Short-Beam Strength of Polymer Matrix Composite Materials and Their Laminates.ASTM International.

ASTM D3039.Standard Test Method for Tensile Properties of Polymer Matrix Composite Materials.ASTM International.

ASTM D2584. Standard Test Method for Ignition Loss of Cured Reinforced Resins. ASTM International.

Foch, B. J. "Integrated Degradation Models for Polymer Matrix Composites", Master of Science Thesis, Massachusetts Institute of Technology, Cambridge, MA. May 1997.

MacNeil, R. "Recovering from the Great Recession: the Outlook for Composites in 2010 and Beyond," Composites 2010: the Composites Exhibition and Convention, Las Vegas, NV, February 9-11, 2010.

Mahieux, C. A. 2006. Environmental Degradation in Industrial Composites, Elsevier, p.12-15.

Mazumdar, S. "Growth Opportunities in the Global Composites Industry", June, 2017, Lucintel, Insights that Matter webpage; http://bit.ly/2EnHhYR. [Accessed 22 January, 2018].

Taktak, R., Guermazi, N., Derbeli, J., and Haddar, N. "Effect of hygrothermal aging on the mechanical properties and ductile fracture of polyamide 6: Experimental and numerical approaches", Engineering Fracture Mechanics, Volume 148, November 2015, p. 122-133. Elsevier.

Zoghi, M., 2014. The international handbook of FRP composites in civil Engineering; Part 1 composites primer edited by Lee, S. L. and Estrada, H. Boca Raton, FL. CRC Press. 